\title{
Mining literature for a comprehensive pathway analysis: A case study for retrieval of homocysteine related genes for genetic and epigenetic studies
}

\author{
Priyanka Sharma1,2, RD Senthilkumar' ${ }^{1}$, Vani Brahmachari², \\ Elayanambi Sundaramoorthy ${ }^{1}$, Anubha Mahajan ${ }^{1}$, Amitabh Sharma ${ }^{1}$ and \\ Shantanu Sengupta*1
}

Address: ${ }^{1}$ Department of Proteomics and Structural Biology, Institute of Genomics and Integrative Biology, Mall Road, Delhi-110007, India and ${ }^{2}$ Dr. B. R. Ambedkar Centre for Biomedical Research, University of Delhi, Delhi-110007, India

Email: Priyanka Sharma - priyankas@igib.res.in; RD Senthilkumar - senindra8@yahoo.com; Vani Brahmachari - vbrahmachari@acbr.du.ac.in; Elayanambi Sundaramoorthy - enambi@igib.res.in; Anubha Mahajan - amahajan@igib.res.in; Amitabh Sharma - asharma@igib.res.in; Shantanu Sengupta* - shantanus@igib.res.in

* Corresponding author

Published: 23 January 2006

Lipids in Health and Disease 2006, 5:I doi:10.1 I86/1476-5 IIX-5-1

This article is available from: http://www.lipidworld.com/content/5/l/l

(C) 2006 Sharma et al; licensee BioMed Central Ltd.

This is an Open Access article distributed under the terms of the Creative Commons Attribution License (http://creativecommons.org/licenses/by/2.0), which permits unrestricted use, distribution, and reproduction in any medium, provided the original work is properly cited.
Received: 15 November 2005

Accepted: 23 January 2006

\begin{abstract}
Homocysteine is an independent risk factor for cardiovascular diseases. It is also known to be associated with a variety of complex disorders. While there are a large number of independent studies implicating homocysteine in isolated pathways, the mechanism of homocysteine induced adverse effects are not clear. Homocysteine-induced modulation of gene expression through alteration of methylation status or by hitherto unknown mechanisms is predicted to lead to several pathological conditions either directly or indirectly. In the present manuscript, using literature mining approach, we have identified the genes that are modulated directly or indirectly by an elevated level of homocysteine. These genes were then placed in appropriate pathways in an attempt to understand the molecular basis of homocysteine induced complex disorders and to provide a resource for selection of genes for polymorphism screening and analysis of mutations as well as epigenetic modifications in relation to hyperhomocysteinemia. We have identified I 35 genes in II 37 abstracts that either modulate the levels of homocysteine or are modulated by elevated levels of homocysteine. Mapping the genes to their respective pathways revealed that an elevated level of homocysteine leads to the atherosclerosis either by directly affecting lipid metabolism and transport or via oxidative stress and/or Endoplasmic Reticulum (ER) stress. Elevated levels of homocysteine also decreases the bioavailability of nitric oxide and modulates the levels of other metabolites including S-adenosyl methionine and S-adenosyl homocysteine which may result in cardiovascular or neurological disorders. The ER stress emerges as the common pathway that relates to apoptosis, atherosclerosis and neurological disorders and is modulated by levels of homocysteine. The comprehensive network collated has lead to the identification of genes that are modulated by homocysteine indicating that homocysteine exerts its effect not only through modulating the substrate levels for various catalytic processes but also through regulation of expression of genes involved in complex diseases.
\end{abstract}




\section{Review}

Elevated levels of homocysteine (hyperhomocysteinemia) has been implicated as an independent risk factor for cardiovascular disease $[1,2]$ and is associated with various other diseases and/or clinical conditions including Alzheimer's disease [3], neural tube defects [4], schizophrenia [5], end-stage renal disease [6], osteoporosis [7] and noninsulin-dependent diabetes [8,9]. Homocysteine, a thiol containing amino acid, is formed during methionine metabolism in the cell. It is a key branch-point intermediate in the ubiquitous methionine cycle, the function of which is to generate one-carbon methyl groups for transmethylation reactions that are essential for several biolog- ical processes (Figure 1). Methionine from dietary sources is converted to S-adenosyl methionine (SAM) by the enzyme S-adenosyl methionine synthase. The methyl group of SAM is required for over 100 known transmethylation reactions, including methylation of macromolecules, phospholipids, myelin, choline and catecholamine. During these reactions SAM is converted by various methyl transferases to S-adenosyl homocysteine (SAH), which is then hydrolyzed to homocysteine and adenosine by S-adenosyl homocysteine hydrolase. This is a reversible reaction with the equilibrium favoring the synthesis of $\mathrm{SAH}$. Homocysteine once formed can either be remethylated to methionine by methionine synthase (MS) or

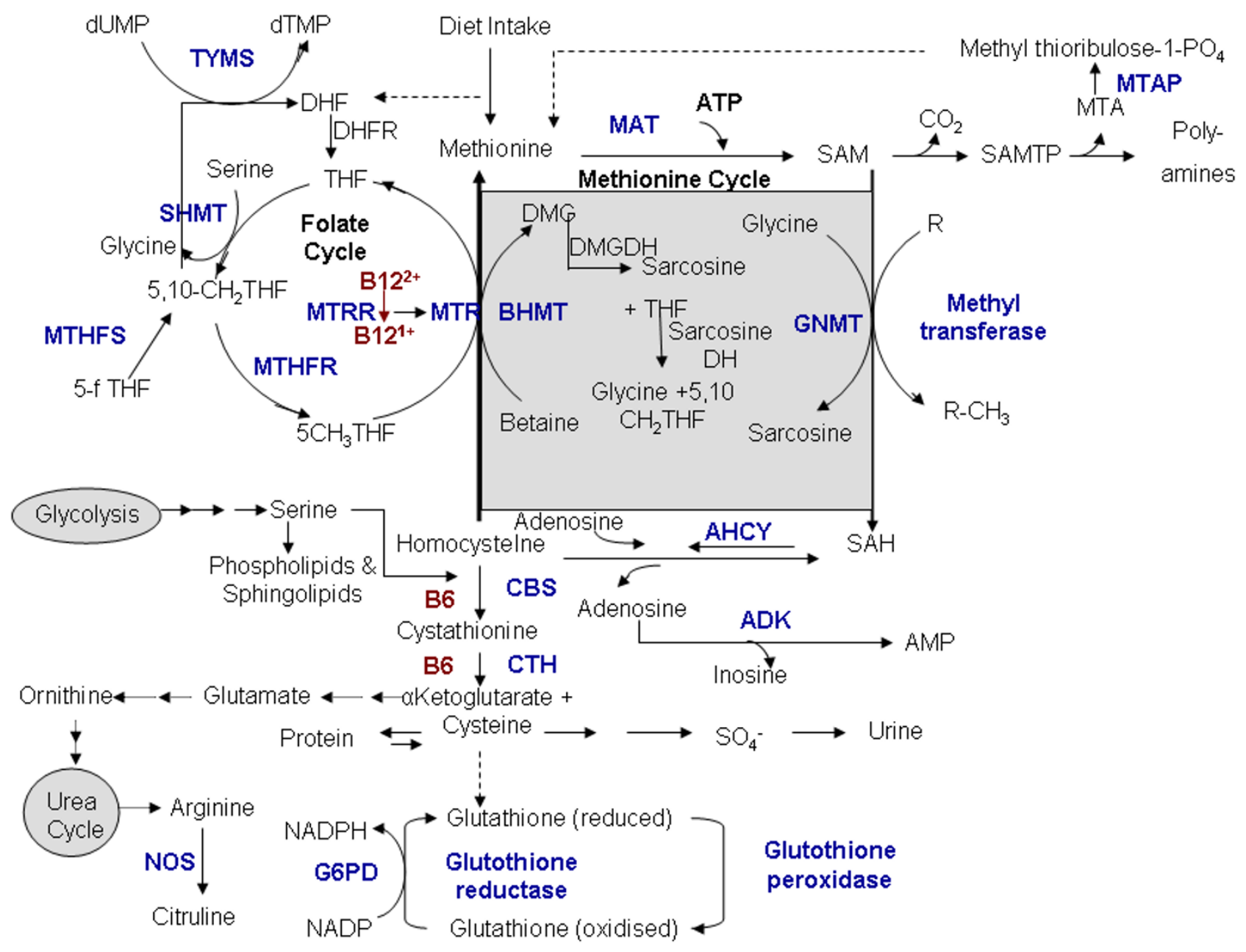

Figure 1

\section{Figure I}

Methionine-Homocysteine metabolism and related pathways. A representation of the methionine cycle (central), transulfuration pathway and its connection to folate cycle, glycolysis pathway and urea cycle. The genes marked in blue have been identified by literature based searches as mentioned in the methods section. The solid and dotted lines indicate direct and indirect (multi step) interaction/ conversion respectively. 
Table I: List of genes identified by literature mining that are modulated by elevated level of homocysteine

\begin{tabular}{|c|c|c|c|}
\hline S.NO & Symbol & Gene Name & Function \\
\hline 1 & Adk & Adenosine kinase & Methionine Metabolism \\
\hline 2 & Agtl & Angiotensin I & Renin - Angiotensin \\
\hline 3 & Ahcyll & S-adenosylhomocysteine hydrolase - like & Methionine Metabolism \\
\hline 4 & $\operatorname{Bax}$ & BCL2-associated $\times$ protein & Apoptosis \\
\hline 5 & $\mathrm{Bcl}-2$ & B-cell cll/lymphoma 2 & Apoptosis \\
\hline 6 & Bhmt2 & Betaine-homocysteine methyltransferase2 & Methionine Metabolism \\
\hline 7 & Calm I & Calmodulin I & Signaling \\
\hline 8 & Proxyl/Cap43 & Protein regulated by oxygen I & Hypoxia \\
\hline 9 & Caspl2 & caspase- 12 & Apoptosis \\
\hline 10 & Casp3 & caspase-3 & Apoptosis \\
\hline 11 & Cav3 & Caveolin & Apoptosis \\
\hline 12 & Ccr2 & Chemokine receptor 2 & Atherosclerosis \\
\hline 13 & Cdk2 & Cyclin-dependent kinase 2 & Apoptosis \\
\hline 14 & Cetp & Cholesteryl ester transfer protein & Lipid metabolism \\
\hline 15 & Cgrp & Calcitonin gene related peptide & Signaling \\
\hline 16 & Cck & Cholecystokinin & Insulin secretion \\
\hline 17 & Clu & Clusterin & Apoptosis \\
\hline 18 & Cmyc & Myc proto-oncogene protein & Apoptosis \\
\hline 19 & Cnp & C-type natriuretic peptide & Vasorelaxant activity. \\
\hline 20 & Crp & C-AMP receptor protein & Apoptosis/signaling \\
\hline 21 & Cubn & Cubilin & Vitamin B 2 Transport \\
\hline 22 & $\mathrm{Cx} 43$ & Connexin43 & Integral to plasma membrane/Signaling \\
\hline 23 & Ccnal & Cyclin AI & Cell cycle \\
\hline 24 & clen & Chloride ion channel gene & Chloride transport \\
\hline 25 & Cyc & Cytochrome & Apoptosis \\
\hline 26 & Demethylase & Demethylase & Metabolism \\
\hline 27 & Dhfr & Dihydrofolate reductase & Metabolism \\
\hline 28 & Dnmtl & DNA Methyltransferase I & Metabolism \\
\hline 29 & Dnmt2 & DNA Methyltransferase 2 & Metabolism \\
\hline 30 & Dnmt3a & DNA Methyltransferase 3 & Metabolism \\
\hline 31 & Erk2 & Extracellular Signal-Regulated Kinase 2 & Signalling \\
\hline 32 & Fak & Focal adhesion kinase & Apoptosis \\
\hline 33 & Fbpl/ Folrl & Folate-Binding Protein I & Folate transport \\
\hline 34 & Fbp2 & Folate-Binding Protein2 & Folate transport \\
\hline 35 & G6pdh & Glucose-6-phosphate dehydrogenase & Metabolism \\
\hline 36 & Gad67 & Glutamic acid decarboxylase 67 & Apoptosis \\
\hline 37 & GaddI 53 & Glutamic acid decarboxylase 153 & Apoptosis \\
\hline 38 & Gadd45 & Glutamic acid decarboxylase 45 & Apoptosis \\
\hline 39 & Gata4 & GATA-Binding Protein 4 & Transcription factor \\
\hline 40 & GPXI & Glutathione Peroxidase & Anti-oxidant \\
\hline 41 & Gshl & GS homeobox I & Transcription Factor \\
\hline 42 & Grp78 & Glucose related protein 78 & Apoptosis \\
\hline 43 & Grp94 & Glucose related protein 98 & Apoptosis \\
\hline 44 & $\mathrm{H} 2 \mathrm{~B}$ & Histone $2 B$ & Histone protein \\
\hline 45 & $\mathrm{H} 3$ & Histone 3 & Histone protein \\
\hline 46 & HDACs & Histone deacetylases & Histone Deacetylation \\
\hline 47 & Hmgcr & Hydroxy-3-Methylglutaryl-Coa Reductase & Lipid metabolism \\
\hline 48 & $\mathrm{Hmt}$ & Homocysteine-S-methyltransferase & Metabolism \\
\hline 49 & $\mathrm{lk} \beta \alpha$ & Inhibitor Of Kappa Light Chain Gene Enhancer & Signaling \\
\hline 50 & IL-I & Interleukin I & Signaling \\
\hline 51 & IL-6 & Interleukin 6 & Signaling \\
\hline 52 & IL-8 & Interleukin 8 & Signaling \\
\hline 53 & Inmt & Indolethylamine $\mathrm{N}$-methyltransferase & Protein methylation \\
\hline 54 & iNOS & Inducible Nitric Oxide Synthase & Nitric oxide stress \\
\hline 55 & Interferon & Interferon & Signaling \\
\hline 56 & Ifg & Ifngamma & Signaling \\
\hline 57 & Ldhd & D-Lactate Dehydrogenase & Metabolism \\
\hline 58 & Ldlr & Low Density Lipoprotein Receptor & Lipid metabolism \\
\hline 59 & Lpl & Lipoprotein lipase & Lipid metabolism \\
\hline
\end{tabular}


Table I: List of genes identified by literature mining that are modulated by elevated level of homocysteine (Continued)

\begin{tabular}{|c|c|c|c|}
\hline 60 & LoxI & Lectin like oxidized LDL receptor-I & Lipid Transport \\
\hline 61 & Lpa & Apolipoprotein & Lipid metabolism \\
\hline 62 & lyase & Lyase & Lipid metabolism \\
\hline 63 & Mcpl & Monocyte Chemoattractant Protein I & Atherosclerosis \\
\hline 64 & Mbd2 & Methyl-CpG-Binding Domain Protein 2 & Methylation binding protein \\
\hline 65 & Mecp2 & Methyl-CpG-Binding Protein 2 & Methylation binding protein \\
\hline 66 & Mapk/Mek & Mitogen-Activated Protein Kinase Kinase & Signalling \\
\hline 67 & Mgmt & O6-methylguanine-DNA methyltransferase & Apoptosis \\
\hline 68 & Mmp3 & Matrix metalloproteinase 3 & Remodeling of extracellular matrix \\
\hline 69 & Mtap & Methyl Thioadenosine Phosphorylase & Metabolism \\
\hline 70 & Mtase & Methyltransferase & Metabolism \\
\hline 71 & NF-K $\beta$ & Nuclear Factor Kappa-B & Signaling \\
\hline 72 & Nmda & $\mathrm{N}$-methyl-D-aspartate receptors & Alzheimer Disease \\
\hline 73 & Nos2 & Nitric Oxide Synthase 2 & Nitric oxide Synthesis \\
\hline 74 & $\mathrm{P} 21$ ras & $\mathrm{P} 2 \mathrm{I}$ ras & Signaling \\
\hline 75 & P38 & Serine /threonine protein kinase belong to MAPK subfamily & Apoptosis \\
\hline 76 & P53 & Tumor protein $\mathrm{p} 53$ & Apoptosis \\
\hline 77 & Pai-I & Plasminogen Activator Inhibitor-I & Blood coagulation \\
\hline 78 & Pam & Peptidylglycine alpha-amidating monooxygenase & Neuro peptide amidation \\
\hline 79 & $\mathrm{Icmt} / \mathrm{Pcmt}$ & Isoprenylcysteine Carboxylmethyltransferase & Signaling. \\
\hline 80 & Pdgf & Platelet-derived growth factor & Inhibits apoptosis \\
\hline 81 & Pemt & Phosphatidylethanolamine (PE) N-Methyltransferase & Methylation of PE \\
\hline 82 & Pkc & Protein kinase $\mathrm{C}$ & Apoptosis \\
\hline 89 & Ppar alpha & Peroxisome Proliferator-Activated Receptor-Alpha & Signaling \\
\hline 84 & PPARgamma2 & Proliferator-Activated Receptor-Gamma2 & Signaling \\
\hline 85 & Prmt & Protein Arginine N-Methyltransferase & Protein methylation \\
\hline 86 & Psl & Presenilin I & Alzheimer Disease \\
\hline 87 & S3a & Ribosomal protein S3A & Structural constituent of Ribosome \\
\hline 88 & Smap8 & smooth muscle-associated protein 8 & Signaling \\
\hline 89 & Srebpl & sterol regulatory element binding protein-I & Lipid Transport \\
\hline 90 & Sst & Somatostatin & Alzheimer Disease \\
\hline 91 & Tdag5। & T-cell death-associated gene $5 \mathrm{I}$ & Apoptosis \\
\hline 92 & TGFbeta & Transforming growth factor beta & Apoptosis \\
\hline 93 & TNFalpha & tumor necrosis factor alpha & Signaling \\
\hline 94 & TNFRSFIB & Tumor necrosis factor receptor 2 gene & Signaling \\
\hline 95 & Timpl & Tissue Inhibitor Of Metalloproteinase I & Signaling \\
\hline 96 & $\mathrm{tPA}$ & Tissue-type plasminogen activator & Blood Coagulation \\
\hline 97 & Vcam I & Vascular Cell Adhesion Molecule I & Cell adhesion/Signaling \\
\hline 98 & Yyl & Yin Yang I & Transcription factor \\
\hline 99 & $\mathrm{~F} 2$ & Coagulation factor II & Blood Coagulation \\
\hline 100 & HemK/PrmC & N5-glutamine AdoMet-dependent methyltransferase & Methylation \\
\hline 101 & $\mathrm{ABCC} 2$ & ATP-Binding Cassette subfamily C & Cellular cisplatin transporter. \\
\hline 102 & Ace & Angiotensin converting enzyme & Renin - Angiotensin \\
\hline 103 & Natl & arylamine $\mathrm{N}$-acetyltransferase type-I & $\begin{array}{l}\text { Detoxification of a plethora of } \\
\text { hydrazine and arylamine drugs }\end{array}$ \\
\hline 104 & Gnmt & Glycine N-Methyltransferase & Methylation \\
\hline 105 & Apo B & Apolipoproteine B & Lipid metabolism \\
\hline 106 & Ins & Insulin & Signalling \\
\hline 107 & Sod & Super Oxide Dismutase & Anti-oxidant \\
\hline 108 & ApoC3 & Apolipoprotein C-III & Lipid metabolism \\
\hline 109 & Atf3 & Activating transcription factor & Transcription factor \\
\hline 110 & ApI & activating protein-I & Transcription factor \\
\hline 111 & Fcmt & Farnesylcysteine methyltransferase & Methylation \\
\hline 112 & Hmox & Heme oxygenase & Biliverdin metabolism \\
\hline
\end{tabular}

betaine hydroxymethyl transferase (BHMT) and/or converted to cystathionine by cystathionine-beta-synthase (CBS). Excess homocysteine is exported into circulation where it rapidly binds to proteins and other small molecules like cysteine. In circulation $<1 \%$ of homocysteine is present in the free reduced form, while $10-20 \%$ of the
tHcy is present as homocysteine-cysteine mixed disulfide and homocystine (dimer of homocysteine), 80-90\% of homocysteine in circulation is protein bound [10]. The essential steps that contribute to the metabolism of homocysteine are outlined in (Figure 1). In healthy well nourished individuals homocysteine metabolism is well 
regulated and the plasma concentration is usually less than $12 \mu \mathrm{M}$. However, genetic defects or nutritional deficiencies lead to elevation of the levels of homocysteine.

Although hyperhomocysteinemia has been associated with several diseases, the mechanism of homocysteineinduced deleterious effects is not fully elucidated. Prominent among the various mechanism proposed for the harmful effects of homocysteine is its ability to modulate the expression of certain genes that may either directly or indirectly lead to several pathological conditions [11]. Homocysteine-induced modulation of gene expression may be due to altered methylation status as the levels of SAH, an inhibitor of many SAM-dependent methyl transferases (Mtase) are elevated during hyperhomocysteinemic conditions $[12,13]$. Apart from the modulation of gene expression due to altered methylation, homocysteine might modulate gene expression by hitherto unknown mechanisms [14].

\section{Methods}

We manually screened all the abstracts from PUBMED, NCBI (up to November 2004) that contained the keywords "homocysteine" and "gene". The genes that are associated with homocysteine could be classified into two broad groups: (i) Genes that are modulated in response to elevated homocysteine levels (Table 1). Modulations of these genes are predicted to result in diseased states. (ii) Genes that are directly or indirectly involved in the modulation of homocysteine levels (Table 2). Defects in these genes, primarily due to single nucleotide polymorphism (SNP) have been, in some cases, shown to elevate the levels of homocysteine. The list was also verified using an inhouse JAVA based text mining tool. We then mapped the genes in appropriate pathways/ networks, using databases that are available in the public domain, in an attempt to elucidate the probable mechanism of homocysteine induced deleterious effects.

\section{Physiological processes that are affected due to homocysteine-induced modulation of gene expression \\ Elevated homocysteine levels and oxidative stress}

One of the mechanisms proposed for the deleterious effects of homocysteine is its ability to generate reactive oxygen species thereby producing oxidative stress (Figure 2 ). It is generally proposed that homocysteine, due to the presence of a thiol group, can rapidly auto-oxidize in circulation in the presence of ceruloplasmin, the major copper binding protein in plasma, to form homocystine and hydrogen peroxide $\left(\mathrm{H}_{2} \mathrm{O}_{2}\right)$, thereby generating oxidative stress [15]. However, several recent reports indicate that transition metal catalyzed oxidation of homocysteine is not a facile process. In fact transition metal catalyzed oxidation of cysteine has been reported to be much faster than that of homocysteine [16] and although the concentration of cysteine is about 20-25 times higher than that of homocysteine it is usually not considered a risk factor for cardiovascular diseases [17]. Therefore, it seems unlikely that the deleterious effect of homocysteine is due to the generation of hydrogen peroxide via metal catalyzed auto-oxidation. However, homocysteine might indirectly result in oxidative stress by decreasing the transcription, translation [18] and catalytic activity of antioxidant enzymes like glutathione peroxidase (GPx) and superoxide dismutase (SOD) [19]. Homocysteine treated bovine aortic endothelial cells showed a significant decrease in glutathione peroxidase activity. The effect of Homocysteine on enzyme activity is demonstrated by compensatory effect of GPx-1 over expression on the adverse effects of homocysteine on endothelial function [20]. Nonaka et al [21] reported that homocysteine decreases the secretion and expression of extra cellular superoxide dismutase (EC-SOD), the most abundant isozyme of SOD, in the vascular wall in rat vascular smooth muscle cells.

Hyperhomocysteinemia has also been reported to be associated albeit indirectly with hypoxic conditions. Supporting this is the expression of Cap43 [that codes for a 43 $\mathrm{kDa}$ protein associated with hypoxia in endothelial cells (EC)] in cells treated with homocysteine. Hypoxia in alveoli leads to damage of capillary wall, a condition predisposing for atherosclerosis. Furthermore, it has also been shown that there is a decrease in the MAT1A transcription and mRNA stability in cultured hepatocytes exposed to hypoxic conditions [22].

Elevated levels of homocysteine have been reported to decrease the bioavailability of endothelial nitric oxide. Under normal condition Nitric oxide (NO) exerts antiatherosclerotic effect through various mechanisms (Table 3 ). The NO produced by endothelium is known to decrease in response to elevated levels of homocysteine [23]. Decrease in the bioavailability of nitric oxide due to increased homocysteine concentration is perceived to cause vasoconstriction thus leading to cardiovascular disorders. Interestingly, the bioavailability of $\mathrm{NO}$ is decreased in hyperhomocysteinemic condition despite normal expression of eNOS [24]. The decrease in the bioavailability of nitric oxide in hyperhomocysteinemic conditions may be attributed to the formation of $\mathrm{S}$ nitrosohomocysteine formed under physiological conditions (Figure 2). NO can also rapidly react with molecular oxygen and other oxygen free radicals to form peroxynitrites (ONOO-) [25-27]. Furthermore, endothelial tetrahydrobiopterin, a critical co-factor for the endothelial nitric-oxide synthase (eNOS) is also a target for oxidation by $\mathrm{ONOO}^{-}$and its oxidation results in formation of trihydrobiopterin radical $\left(\mathrm{BH}^{\bullet}\right)$ and consequently decrease 
Table 2: List of genes identified by literature mining that modulate homocysteine levels

\begin{tabular}{|c|c|c|c|}
\hline S.No & Symbol & Gene Name & Function \\
\hline I. & Mthfr & Methylenetetrahydrofolate Reductase & $\begin{array}{l}\text { Conversion of 5, 10-methylene-tetrahydrofolate to 5-methyl- } \\
\text { tetrahydrofolate. }\end{array}$ \\
\hline 2. & Cbs & Cystathionine beta-synthase & Condensation of homo-cysteine and serine to form cystathionine \\
\hline 3. & Mtr & $\begin{array}{l}\text { Methyltetrahydrofolatehomocysteine } \\
\text { methyltransferase }\end{array}$ & Remethylation of homocysteine to methionine \\
\hline 4. & Mtrr & Methionine synthase reductase & $\begin{array}{l}\text { Reductive regeneration of cob( }(I) \text { alamin cofactor required for the } \\
\text { maintenance of } M T R \text { in a functional state }\end{array}$ \\
\hline 5. & Rfc-I & Reduced-folate carrier & 5-methyl-tetrahydrofolate internalization in cell \\
\hline 6 & Gcp II/Folh I & Glutamate Carboxypeptidase II & $\begin{array}{l}\text { Polyglutamate converted to monoglutamate folate by action of the } \\
\text { enzyme folylpoly gammaglutamate carboxy-peptidase (FGCPI), an enzyme } \\
\text { expressed by GCPII. }\end{array}$ \\
\hline 7 & eNos & Endothelial Nitric oxide synthase & Conversion of L-Arginine to L-Citrulline and nitric oxide synthase (NO) \\
\hline 8. & Tc II & Transcobalamine II & Transport of vitamin $\mathrm{B} 12$ \\
\hline 9. & Shmt I & Serine Hydroxymethyltransferase I & $\begin{array}{l}\text { Reversible conversion of serine and tetrahydrofolate to glycine and } 5,10 \text { - } \\
\text { methylene tetrahydrofolate. }\end{array}$ \\
\hline 10. & Tyms & Thymidylate Synthase & $\begin{array}{l}\text { 5, I0-methylene THF and deoxyuridylate to form dihydro-folate and } \\
\text { thymidylate. }\end{array}$ \\
\hline 11 & Cth & Cystathionine Gamma-Lyase & Hydrolysis of cystathionine to cysteine and $\alpha-$ Ketoglutarate \\
\hline 12 & Mthfd & Methylene-tetra hydrofolate dehydrogenase & $\begin{array}{l}\text { Conversion of 5, 10-methylene-tetrahydrofolate to } 5,10 \text { methenyl- } \\
\text { tetrahydrofolate. }\end{array}$ \\
\hline 13 & Mthfs & Methenyltetrahydrofolate synthetase & $\begin{array}{l}\text { Conversion of } 5 \text {-formyltetrahydrofolate to } 5,10 \text { - } \\
\text { methenyltetrahydrofolate. }\end{array}$ \\
\hline 14 & Apo $E$ & Apolipoproteine E & $\begin{array}{l}\text { Mediates the binding, internalization, and catabolism of lipoprotein } \\
\text { particles. }\end{array}$ \\
\hline 15 & Vegf & Vascular endothelial growth factor & $\begin{array}{l}\text { Growth factor active in angiogenesis, vasculogenesis and endothelial cell } \\
\text { growth. }\end{array}$ \\
\hline 16 & Ponl & Paraoxonase I & $\begin{array}{l}\text { Hydrolyzes the toxic organo-phosphorus. It also mediate an enzymatic } \\
\text { protection of LDL against oxidative modification. }\end{array}$ \\
\hline 17 & Bhmt & Betaine-homocysteine methyltransferase & $\begin{array}{l}\text { In Liver \& kidney it catalyses the conversion of betaine to dimethyl glycine } \\
\text { (DMG). }\end{array}$ \\
\hline 18 & MatIA & Methionine Adenosyltransferase IA & $\begin{array}{l}\text { Methionine to SAM by transfer of the adenosyl moiety of ATP to the } \\
\text { sulfur atom of methionine }\end{array}$ \\
\hline 19 & Ahcy & S-adenosylhomocysteine hydrolase & Hydrolysis of AdoHcy to adenosine and homocysteine \\
\hline 20 & $\mathrm{Cbl}$ & Cystathionine beta lyase & Conversion of cystathionine to homocysteine. \\
\hline 22 & Factor $\mathrm{V}$ & Coagulation factor $\mathrm{V}$ & $\begin{array}{l}\text { Cofactor for the factor Xa-catalyzed activation of prothrombin to the } \\
\text { clotting enzyme thrombin. }\end{array}$ \\
\hline 23 & Pai-I & Prothrombin activator inhibitor-I & Inhibition of fibrinolysis by inhibiting the plasminogen-activator and t-PA. \\
\hline
\end{tabular}

NO production $[28,29]$. Thus, elevated levels of homocysteine may lead to the accumulation of reactive oxygen species due to the decreased activity of antioxidant enzymes and these oxygen radicals could then potentially inactivate $\mathrm{NO}$ resulting in vasoconstriction.

Another potential mechanism for the decreased bioavailability of NO in hyperhomocysteinemic states is the increased generation of asymmetric dimethylarginine (ADMA), an analogue of L-arginine, which is a competitive inhibitor of eNOS [30]. ADMA also promotes the "uncoupling" of eNOS (Figure 2) leading to increased production of superoxide $\&$ other reactive oxygen species, which may cause further decrease in availability of NO. ADMA is produced during degradation of proteins containing methylated arginine residues by protein arginine $\mathrm{N}$ - methyltransferases (PRMTs) [31]. The increased SAM dependent generation of these methylated proteins, results in both increased production of ADMA and increased generation of homocysteine [32]. The inhibition of endothelial nitric oxide synthesis by ADMA impairs cerebral blood flow, which may contribute to the development of Alzheimer's disease [33].

Furthermore, one of the mechanisms proposed for the anti-thrombotic effect of $\mathrm{NO}$ is its ability to inhibit the expression of the prothrombotic protein PAI-1. It has also been shown that NO released from activated platelets inhibits the recruitment of platelets to the growing thrombus [34]. Thus decrease in NO concentration may result in increased expression of PAI-1 and platelet aggregation leading to thrombosis.

Intracellular oxidative stress may be either due to excessive generation of reactive oxygen species or to decreased ability of cells to scavenge the reactive oxygen species lead- 
ing to its accumulation. We propose that homocysteineinduced oxidative stress is primarily due to the decreased ability of the cells to detoxify $\mathrm{H}_{2} \mathrm{O}_{2}$ \& other lipid peroxides due to decreased activity of intracellular antioxidant enzymes. Furthermore, decreased bioavailability of nitric oxide may lead to the increased expression of pro-inflammatory cytokines and PAI which can potentially lead to cardiovascular diseases.

\section{Hyperhomocysteinemia: apoptosis and inflammatory pathways}

The major process linking levels of homocysteine with apoptosis and inflammatory pathway is the Endoplasmic Reticulum (ER) stress (Figure 3, branch 3,) and c-myc mediated signaling (Figure 3, branch 2). Endoplasmic Reticulum is the destination for secretary and extracellular proteins. It also serves as a site of calcium storage, calcium signaling, and biosynthesis of steroids, cholesterol \& other lipids. The ER has high level of numerous resident chaperone proteins such as glucose-regulated proteins, GRP-78 \& GRP-94, which under normal conditions are required for proper protein folding prior to export, to their destination. However, during energy deprivation these proteins initiate signal of ER stress, a condition in which unfolded \& misfolded proteins accumulate $[35,36]$. Homocysteine has been shown to alter the cellular redox state resulting in ER stress [37]. Homocysteine increases the expression and synthesis of GRP78, a glucose-regulated protein that is induced during ER stress. Cells respond to ER Stress by various processes, prominent among these is a process known as unfolded protein response (UPR) mediated by ER-resistant trans-membrane protein kinase (IRE1) [38]. Furthermore, Homocysteine was found to induce the expression of glutamic acid decarboxylase (GADD45, GADD 153), ATF4 (Figure 3, branch 3) and YY1 [[38], Figure 3, branch 4] as well as RTP and HERP $[39,40]$. Interestingly, in a separate study it has been reported that inducers of GRP78 also increase the expression of these genes [41]. The GADDs also link homocysteine levels with ER stress and alterations in cell growth and proliferation. In addition, YY1, a member of GL1 zinc finger family enhances the transcription activation of GRP78 promoter under a variety of ER stress conditions $[42,43]$. Increased expression of YY1 mediates the stress signal from ER to nucleus.

However, exposure to excess ER stress results in apoptotic cell death. ER stress activates c-Jun N-terminal kinases (JNKs) that regulate gene expression via phosphorylation and activation of transcription factors such as c-JUN. The activation of JNK is mediated by TNF receptor-associated factor-2 (TRAF2), which transduce signals from IREs that act as stress sensors and initiates UPR [44]. TRAF2 activates the apoptosis-signaling kinase (ASK1) or MAPKKK (mitogen activated protein kinase kinase kinase). Activa- tion of MAPKKK leads to activation of JNK protein kinase that in turn causes apoptosis [45]. The TRAF1 binds to the TRADD (TNFR-Associated Death Domain), which recruits the activated caspase 8 initiating a proteolytic cascade subsequently resulting in apoptosis. Furthermore, caspase 8 also leads to release of pro-apoptotic factor cytochrome $\mathrm{C}$ [46]. Homocysteine may induce oxidative stress and apoptosis through an NADPH oxidase and/or JNKdependent mechanism(s) [47]. Extra cellular adenosine (Ado) along with homocysteine (Ado/Hcy) causes apoptosis of cultured pulmonary artery endothelial cells through the enhanced formation of intracellular S-adenosylhomocysteine (Figure 3, branch 1). SAH inhibits isoprenylcysteine carboxylmethyltransferase (ICMT), which results in decrease of Ras methylation and activation of downstream signaling molecules resulting in apoptosis. ICMT catalyzes the posttranslational methylation of isoprenylated C-terminal cysteine residues found in many signaling proteins such as small monomeric $G$ proteins $[48,49]$. Similarly high concentration of adenosine results in apoptosis of L1210 lymphocytic leukemia cells. Apoptosis in these cells was preceded by an early but transient expression of the proto-oncogene c-myc [50].

Expression of c-myc sensitizes cells to a wide range of proapoptotic insults that include DNA damage, hypoxia and nutrient deprivation (Figure 3, branch 2). The pro -apoptotic effect of c-myc is mediated through the release of cytochrome $\mathrm{C}$ into the cytosol [51]. Holocytochrome C interacts with apoptotic protease activating factor (APAF1 ), which then recruits and activates procaspase 9. This ternary complex triggers the autocatalytic processing of

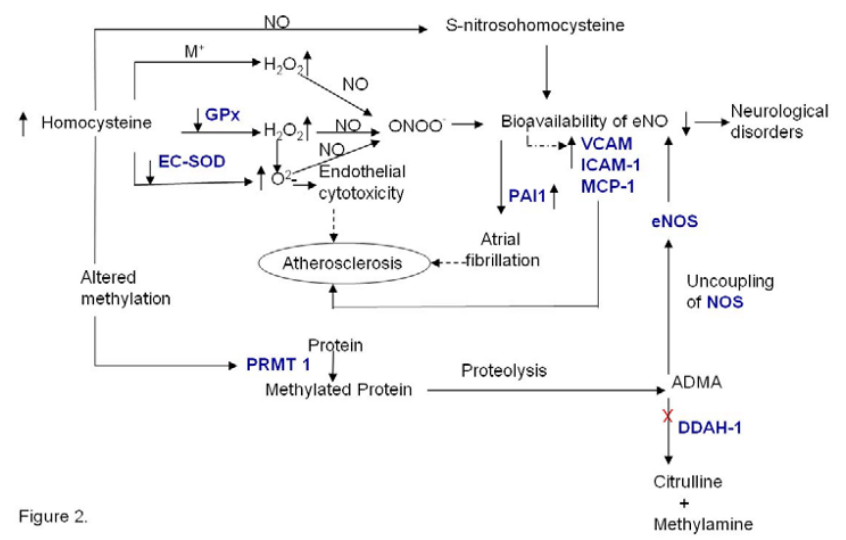

Figure 2

Hyperhomocysteinemia and Oxidative Stress. Homocysteine might directly or indirectly lead to oxidative stress via the pathways shown in the figure. The genes marked in blue have been identified by literature based searches as mentioned in the methods section. The solid and dotted lines indicate direct and indirect (multi step) interaction/ conversion respectively. $\mathbf{X}$ - Inhibition 
Table 3: Mechanisms mediating the anti-atherosclerotic effect of nitric oxide

\begin{tabular}{ll}
\hline Anti-atherosclerotic effect of nitric oxide & Reference(s) \\
\hline $\begin{array}{l}\text { Promotion of SMC proliferation } \\
\text { Inhibition of platelet aggregation }\end{array}$ & 131 \\
$\begin{array}{l}\text { Reduction in endothelial activation \& Inhibition of } \\
\text { MCP-I }\end{array}$ & 132 \\
Stabilizes NF-K $\beta$ inhibitor, Ik $\beta \alpha$ & 135 \\
Inhibition of LDL oxidation \& lipid peroxidation & 136,137 \\
Reduces super oxide generation & 138 \\
$\begin{array}{l}\text { Decrease the Expression of PAl-I } \\
\text { Nitric oxide regulates vascular cell adhesion } \\
\text { molecule I gene expression }\end{array}$ & 34 \\
\end{tabular}

caspase 9 and subsequently activates caspase 3. However inhibition of CD95 and P53 signaling pathway does not block this release, but activation of the caspase dependent apoptotic machinery requires cooperation between c-myc induced cytochrome $\mathrm{C}$ release and CD95 signaling. Thus, c-myc induction leads to release of cytochrome $\mathrm{C}$ to the cytosol recruiting the cells to other apoptotic triggers like CD95 pathway or p53 activation. C-myc might also induce apoptosis through active response factor (ARF) expression via activation of P53 [52]. Recently it has been shown that homocysteine induced apoptosis in human umbilical vein endothelial cells is correlated with p53 dependent Noxa expression [53]. The expression of the Noxa gene involves direct activation of its promoter by p53. Interestingly, the activity of p53 is regulated through lysine methylation. Methylated p53 is restricted to the nucleus and has increased stability. The "hyper-stabilization" and activation of p53 result in cell cycle arrest and apoptosis [54]. The methyltransferase activity is critical for p53 dependent apoptosis. Thus, it can be perceived that in hyperhomocysteinemic state p53 lysine methylation could be inhibited. Homocysteine could also potentially inhibit endothelial cell growth by inhibiting the expression of cyclin A mRNA. Apart from cyclin A associated kinase activity, cyclin dependent kinase (CDK2) activity was also significantly inhibited [55]. Interestingly, stress induced activation of P53 promotes transcription of P21, which in turn binds to CDKs and leads to blocking of the G1 to S phase transition during cell cycle.

Homocysteine affects mitogenesis in a cell type specific manner. Although elevated levels of homocysteine lead to apoptosis and has growth inhibitory effect on endothelial cells, it leads to proliferation of smooth muscle cells eg. homocysteine enhances AP-1 activity in A7r5 aortic smooth muscle cells thus influencing cell proliferation [56]. In a recent report it was shown that elevated levels of homocysteine result in increased AP-1 nuclear protein binding, cell DNA synthesis and proliferation in mesangial cells by increasing Erk activity via a calcium-dependent mechanism [[57], Figure 3, branch 5]. Furthermore, homocysteine has been reported to up regulate the expression of VEGF mRNA in pigmented human endothelial cell line via ATF4 mediated activation. [58]. The cell survival signal from VEGF is mainly brought about by P13-mediated activation of Akt/PKB. The downstream targets for Akt/PKB pathway inhibit apoptosis. Furthermore, VEGF also leads to the induction of Raf-MEK -ERK pathway in human umbilical endothelial cells (HUVECs) relating to cell survival [59].

Apart from activating the unfolded protein response, homocysteine-induced ER stress also activates the sterol regulatory binding proteins (SREBPs). Homocysteine induces the expression of sterol regulatory element binding protein-1 (SREBP1, Figure 3), an ER membrane bound transcription factor, in cultured vascular endothelial cells and human hepatocyte leading to increased biosynthesis and uptake of cholesterol, triglycerides and accumulation of intracellular cholesterol $[60,61]$. Normally the expression and activity of SREBPs is regulated by SREBP cleavage activation protein (SCAP). However, it is believed that homocysteine circumvents this mechanism, maintaining the cells in sterol-starved state although lipids continue to accumulate.

Thus by mapping the genes (identified using literature based search) in appropriate pathway, we show that elevated levels of homocysteine cause the up regulation of ER stress proteins resulting in apoptosis. Homocysteine might also mediate apoptosis via P53 mediated pathway or by inhibition of methyl transferases like ICMT. Furthermore, ER stress also leads to altered lipid metabolism which may lead to cardiovascular disorders. Thus, homocysteine-induced ER stress emerges as the common pathway that relates to apoptosis and atherosclerosis. In this context it needs to be mentioned that homocysteine can potentially cleave critical protein disulfide bonds resulting in the alteration of structure and/or function of the protein [62-64]. It can be perceived that this might also lead to protein misfolding/unfolding which is a hallmark of ER stress.

\section{Hyperhomocysteinemia and the coagulation cascade}

During vascular injury, tissue factor, an integral membrane glycoprotein that is tightly associated with phospholipids, form a complex (1:1) with factor VII thereby initiating the coagulation cascade (Figure 4). Homocysteine can enhance the pro-coagulant activity in a number of ways. Elevated homocysteine levels have been reported to increase the cellular tissue factor activity [65]. Mann et al [63] also suggested that homocysteine rapidly incorporates into factor $\mathrm{V}$ resulting in impaired inactivation of factor Va by activated protein C (APC). Binding of homocysteine to factor $\mathrm{V}$ however did not have any effect 
on the conversion of factor $\mathrm{V}$ to factor $\mathrm{Va}$. APC, a vitamin $\mathrm{K}$ dependent protein is formed by the action of thrombin on protein $\mathrm{C}$ in the presence of a membrane bound cofactor, thrombomodulin. Interestingly, homocysteine has also been shown to inhibit the cofactor activity of thrombomodulin [66]. Thus homocysteine impairs the thrombomodulin-APC anticoagulant pathway by inhibiting the cofactor activity of thrombomdulin resulting in the decreased formation of APC and also by inhibiting the inactivation of factor Va by APC. Furthermore, homocysteine also affect another important endothelial anticoagulant pathway viz. endothelial cell heparin-like glycosaminoglycans-antithrombin III anticoagulant mechanism [67]. It has been reported that incubation of endothelial cells with homocysteine suppresses the amount of antithrombin III binding to cell surface. Homocysteine also reduces the cellular binding for tissue plasminogen activator and enhances the plasminogen activator inhibitor-1 (PAI-1) gene expression and secretion from vascular endothelial and smooth muscle cells by a mechanism independent from paracrine-autocrine activity of TGF beta and TNF alpha. Hajjar et al also suggested that endothelial cells treated with homocysteine resulted in selective reduction in cellular binding sites for t-PA. This $65 \%$ decrease in binding was associated with a $60 \%$ decrease in cell-associated t-PA activity [64]. Thus homocysteine may promote prothrombotic state.

Thus, it can be perceived that elevated homocysteine levels will lead to prothrombotic state by enhancing the procoagulant pathway and/or suppressing the anticoagulant pathways.

\section{Hyperhomocysteinemia and atherosclerosis}

Atherosclerosis is a chronic inflammatory disease of the artery, in which deposits of fatty substances, cholesterol, cellular waste products, calcium and other substances build up in endothelial layer of artery [68]. Apart from the conventional risk factors for atherosclerosis, elevated level of homocysteine is now considered to be an independent risk factor for cardiovascular diseases. Several mechanisms have been proposed for the homocysteine induced cardiovascular disease including altered lipid metabolism, cholesterol dysregulation, modulation of extracellular matrix protein expression, inflammatory response and oxidative stress. From the genes obtained after literature mining we found that homocysteine might induce atherosclerosis via one or more of the pathways depicted in Figure 5. The various interlinked pathways that contribute to the complex phenotype of atherosclerosis are outlined below.

\section{I) Homocysteine mediates cholesterol dysregulation}

Homocysteine plays an important role in cholesterol biosynthesis by inducing the transcription as well as transla- tion of 3-hydroxy-3- methylglutaryl coenzyme A reductase (HMGCR), the rate-limiting enzyme in the cholesterol biosynthesis (Figure 5, branch 1). It also increases cholesterol synthesis and accumulation in endothelial cells [69]. Inhibitors of HMGCR like simvastatin prevented the homocysteine-induced accumulation of cholesterol. Thus, it can be perceived that elevated levels of homocysteine result in cholesterol biosynthesis dysregulation. Furthermore, as mentioned earlier, sterol regulatory element-binding protein-2 (SREBP), a transcription factor, is activated in the liver of hyperhomocysteinemic rats and the activation of SREBP-2 leads to hepatic lipid accumulation by regulating HMG-CoA reductase expression in the liver [70]. Hyperhomocystenemia also modulates cholestrol biosynthesis pathway through upregulation of the ER chaperone, GRP78/BiP in hepatocytes while the actual transport of the cholesterol in endothelial cells was found to be downregulated leading to upregulation of HMGCR in endothelial cells [71].

\section{li) Homocysteine affects LPL and Lox-I expression, which leads to atherosclerosis}

Homocysteine has been found to induce the expression of macrophage lipoprotein lipase (LPL) both at the transcription and translation level presumably via PKC activation [[72], figure 5, branch 6]. LPL is the major lipolytic enzyme involved in hydrolysis of triglycerides in lipoproteins [73]. It is secreted by macrophages in atherosclerotic lesions and macrophage LPL produced in the vascular wall acts as a pro-atherogenic protein. This enzyme mediates the uptake of lipoproteins by macrophages, promotes lipoprotein retention to the extracellular matrix, induces the expression of the proatherogenic cytokine TNF- $\alpha$, increase monocyte adhesion to endothelial cells and proliferation of vascular smooth muscle cells. It also promotes foam cell formation and atherosclerosis in vivo. Homocysteine was found to simultaneously change macrophage LPL \& c-fos mRNA levels and induce the binding of nuclear protein to AP1 sequence (Figure 5, branch 7). This suggests that $\mathrm{c}$-fos also may have a role to play in the stimulatory effect of homocysteine on macrophage LPL mRNA expression.

Homocysteine is known to down regulate the expression of peroxisome proliferators-activated receptors (PPARs) that are redox sensitive transcription factors in the vasculature belonging to the ligand-activated nuclear receptor family (Figure 5, branch 9). They play a key role in regulating expression of genes that control glucose and lipid metabolism and has been implicated in metabolic disorders leading to atherosclerosis. PPAR agonists like fibrates are known to promote anti-inflammatory effects presumably via the induction of antioxidant enzymes by PPARs. Homocysteine can potentially bind to PPARs and compete with the PPAR ligands like fibrates [74]. In fact it has 


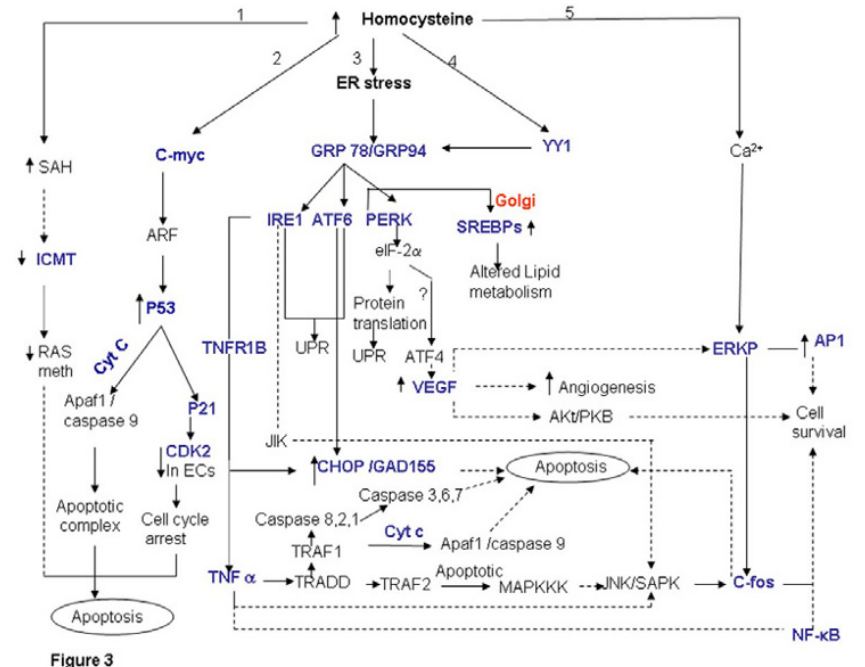

Figure 3

Elevated homocysteine levels and apoptosis. Elevated levels of homocysteine directly (branch I and 2) or via ER stress (branch 3 and 4) lead to apoptosis. Homocysteine also might lead to cell survival via calcium dependent ERK phosphorylation (branch 5). The genes marked in blue have been identified by literature based searches as mentioned in the methods section. The solid and dotted lines indicate direct and indirect (multi step) interaction/ conversion respectively.

been reported that homocysteine binds to PPARs with a 10 fold higher affinity than fibrates [74], a class of lipidmodifying agents that have been widely used to substantially decrease plasma triglyceride levels. It also results in moderate decrease in LDL cholesterol and an increase in HDL cholesterol concentrations. Thus, elevated levels of homocysteine might lead to hyperlipidemia by competing with the PPAR ligands like fibrates which are known to catabolise VLDL and triglycerides [75].

Oxidized low density lipoprotein (OxLDL) (Figure 5, branch 8) is one of the major factor that is responsible for endothelial dysfunction is as it induces expression of adhesion molecules, chemokines like MCP1 and impairs the endothelium-dependent vasorelaxation. LOX-1 is the principle receptor of OxLDL in vascular endothelial cells. Homocysteine has been reported to enhance endothelial LOX-1 gene expression and TNF $\alpha$ release upon oxLDL stimulation [[76,77] Figure 5, branch 3]. Tontonoz et al demonstrated that oxLDL induces PPAR- $\gamma$ in foam cell of atherosclerotic lesion, thus potentiating pathogenesis of atherosclerosis [78]. Oxidized LDL has a role in the activation of PPAR- $\gamma$ dependent gene expression and regulation of oxLDL receptor CD36. Thus, activation of PPAR- $\gamma$ and CD36 constitute a positive feedback loop to potentiate the effects of oxLDL. PPAR $\alpha$ and PPAR- $\gamma$ can also suppress the inflammatory gene expression in monocytes, $[79,80]$ and

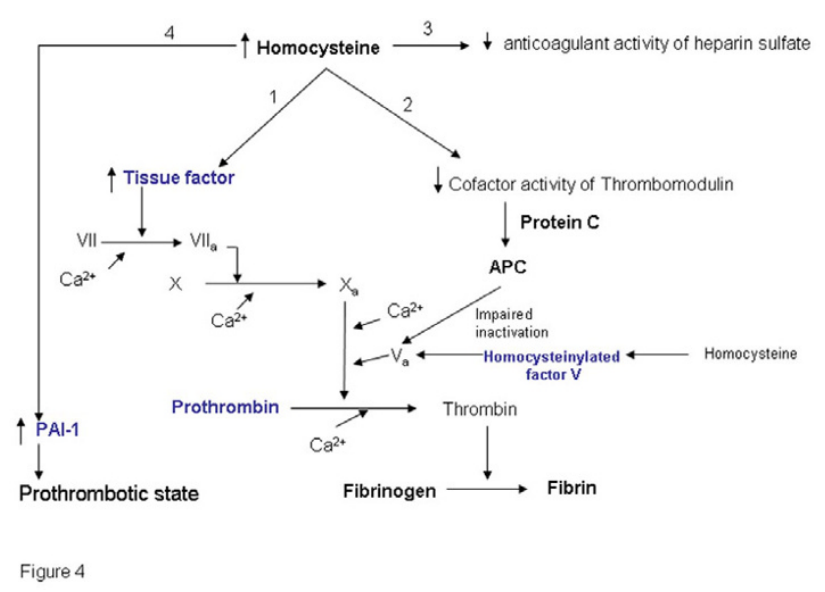

Figure 4

Elevated homocysteine levels and the Coagulation pathway. Elevated homocysteine levels may lead to thrombosis either by increasing the activity of the tissue factor (branch I) thereby facilitating the coagulation cascade or by inhibiting the anticoagulant pathways (branch 2 and 3). The genes marked in blue have been identified by literature based searches as mentioned in the methods section. The solid and dotted lines indicate direct and indirect (multi step) interaction/ conversion respectively.

mediate the anti-inflammatory response in the vessel wall. Hence, a balance between pro inflammatory effect of oxLDL and anti-inflammatory properties of PPARs determine the inflammatory status of cell/ vessel wall. Recent cross sectional studies report that oxidized LDL have higher association with angiographically documented coronary artery disease in patients 60 years or younger which implies that early onset CAD is more correlated with oxidized LDL thus by upregulating oxidized LDL receptors homocysteine induces athreosclerotic changes in an independent manner in both endothelial cells as well as mononuclear cells accelerating the rate of atherosclerosis [81].

\section{(iii) Homocysteine modulates inflammatory gene response in endothelial cells}

In endothelial cells, proinflammatory cytokines enhance the binding of NF- $\mathrm{KB}$ to DNA and cause up-regulation of NF- $\kappa B$ dependent genes [82,83] (Figure 5, branch 6) Homocysteine has been reported to induce NF-кB activation in HUVECs and human aortic endothelial cells (HAECs). It also activates IкB- $\alpha$ resulting in nuclear translocation of NF- $\kappa B$ and enhanced NF- $\mathrm{B}$ /DNA interaction. Thus, homocysteine cause an imbalance in intracellular signaling rather than a complete suppression of endothelial cell function. NF- $\mathrm{KB}$ may also play an important role in homocysteine-induced MCP-1 expression leading to monocyte macrophage accumulation in atherosclerotic 


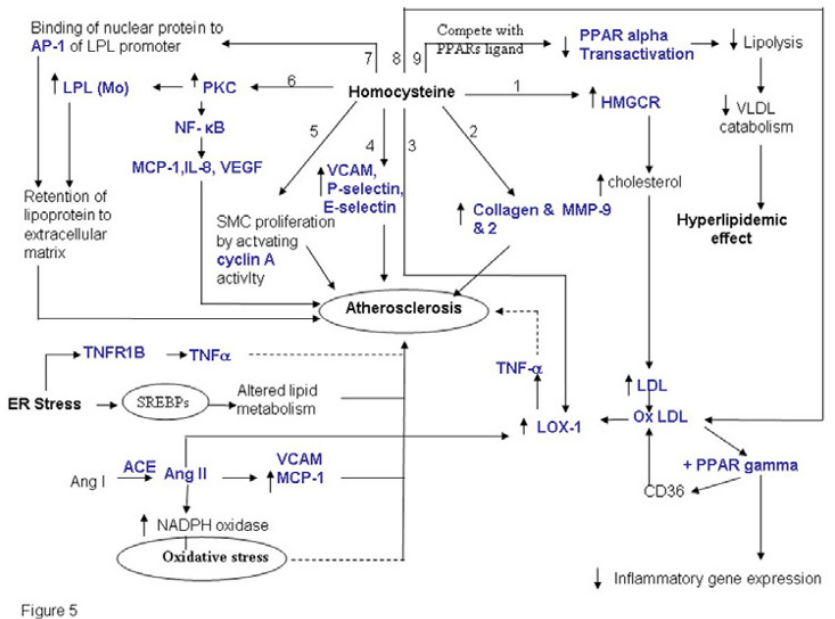

Figure 5

Elevated Homocysteine is associated with atherosclerosis. Elevated level of homocysteine affects the cholesterol biosynthesis (branch I), expression of extracellular matrix proteins (branch 2), enhance endothelial LOX-I gene expression and TNF $\alpha$ release upon oxLDL stimulation (branch 3,branch 8), affect the expression of cell adhesion molecule (branch 4), enhance SMC proliferation by increasing cyclin A activity (branch 5), induce the expression of LPL both at the transcription and translation level presumably via PKC activation (branch 6,7) that modulates inflammatory gene response in endothelial cells. Elevated level of homocysteine also down regulate the expression of PPARs (Figure 6 , branch 9). The genes marked in blue have been identified by literature based searches as mentioned in the methods section. The solid and dotted lines indicate direct and indirect (multi step) interaction/ conversion respectively.

lesions. Wang et. al [84] demonstrated that in homocysteine treated vascular smooth muscle cells both mRNA and protein levels of MCP-1 were increased through activation of $\mathrm{PKC}$ and superoxide production followed by NF- $\kappa$ B activation. MCP-1 \& IL-8 are major chemokines for leukocyte trafficking and has been found in atheromatous plaques. The major route of action of MCP-1 is via its interaction with MCP-1 receptor on surface of monocyte (CCR2). Homocysteine stimulates CCR2 expression in monocyte leading to an enhanced binding and chemotactic response [84]. Apart from MCP-1, homocysteine also up regulate the expression of IL- 8 in cultured human monocyte via enhanced formation of homocysteine induced ROS (Reactive Oxygen species) [85]. Homocysteine also induces expression of VEGF presumably via activation of NF- $\kappa \mathrm{B}[86]$. VEGF has been found to be expressed in activated macrophages, endothelial cells, and smooth muscle cells in human coronary atherosclerotic lesions, but not in normal artery [87]. VEGF has also been reported to increase atherosclerotic plaque size [88].

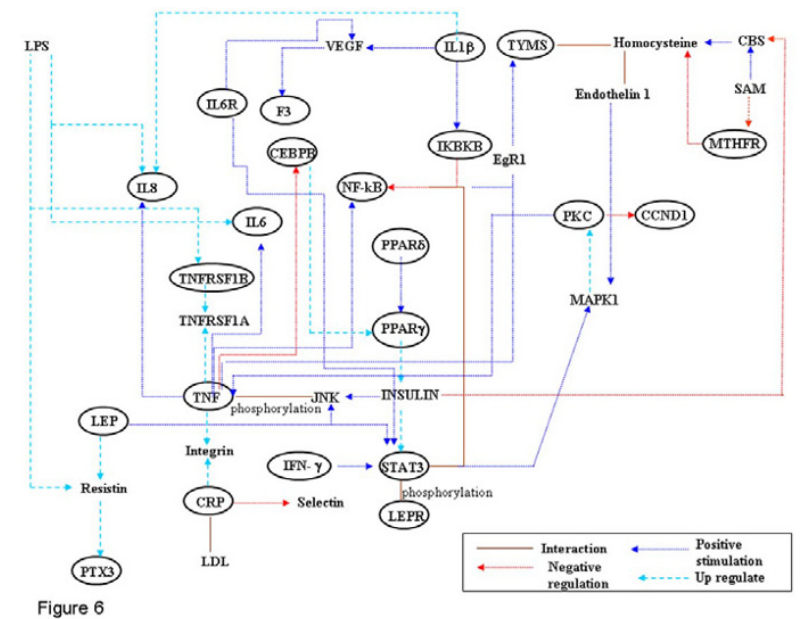

Figure 6

Interactions between proinflammatory cytokines. The interaction between different proinflammatory cytokines is shown which may be modulated by homocysteine levels resulting in pathological consequences.

Moreover, in endothelial cells homocysteine modulates the expression of cell adhesion molecule-1 (sCAM-1) [89] which is generally perceived as a marker for vascular inflammation. Mansoor et. al. recently reported increase in the concentration of plasma homocysteine and triglycerides six hours after methionine and/or fat loading. It resulted in significant increase in the concentrations of $\mathrm{P}$ selectin, E-selectin and VCAM-1 in healthy volunteers [90](Figure 5, branch 4).

Increasing evidence suggests the role of hyperhomocysteinemia in the underlying pathophysiological mechanism of the increased vascular risk development of coronary artery disease in patients with T2DM (Type 2 Diabetes Mellitus). The mechanisms by which homocysteine promotes this and exerts its detrimental effects may relate to induction of endothelial dysfunction and/or chronic inflammation (Figure 5, branches 4-6). T2DM stems from the failure of the body to respond normally to insulin, called "insulin resistance", ultimately leading to hyperglycemic condition. This common form of diabetes is often associated with obesity. Studies on experimental models have suggested that obesity also is a state of chronic inflammation. Over the years increasing evidence has accumulated indicating an ongoing cytokine-induced acute-phase response (low-grade inflammation) to be closely involved in the pathogenesis of T2DM and associated complications such as dyslipidemia and atherosclerosis. Observation that plasma concentrations of proinflammatory markers viz. C-reactive protein (CRP), interleukin-6 (IL-6), plasminogen activator inhibitor-1 (PAI-1) and tumor necrosis factor- $\alpha$ (TNF- $\alpha$ ) in the obese 


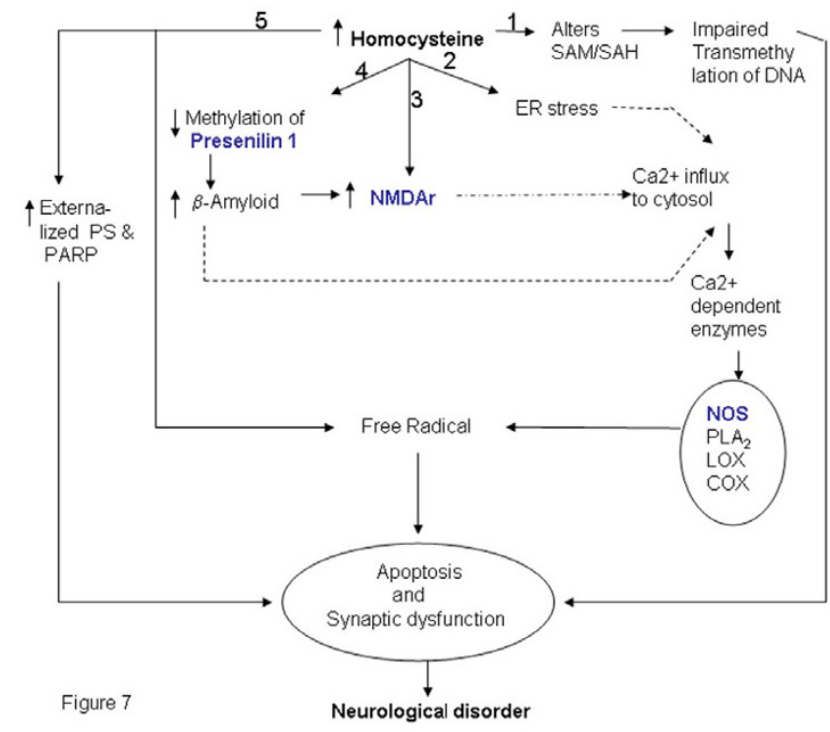

Figure 7

Pathways that link elevated homocysteine level with Neurological disorders. Elevated homocysteine levels may cause neurological diseases by various mechanisms which include), altered methylation (branch I \& 4), ER stress (branch 2), direct interaction with receptors (branch 3 ) and biomarker of apoptosis (branch 4). The Symbols shaded in color are the gene names given included in the gene-list. The genes marked in blue have been identified by literature based searches as mentioned in the methods section. The solid and dotted lines indicate direct and indirect (multi step) interaction/ conversion respectively.

are elevated has confirmed the same. The interactions between the proinflammatory cytokines are shown in (figure 6). Association of hyperhomocysteinemia with elevated levels of proinflammatory cytokine in T2DM patients substantiates its role in accelerating diabetes associated atherosclerosis [91]. Impaired SAM synthesis in liver tissue has also been shown to enhance production of pro-inflammatory cytokines and mediators [92].

\section{V) Hypertension, angiotensin II and atherosclerosis}

Hypertension is a risk factor for cardiovascular disease, and experimental evidence supports a role of renin-angiotensin system in contributing to pathogenesis of atherosclerosis [[93], Figure 5]. Untreated hypertension is associated with disturbed glutathione redox status and increased plasma homocysteine concentrations [94]. Hypertension associated with the elevation of angiotensin II levels results in the induction of smooth muscle cell superoxide via NADPH oxidase $[95,96]$. In addition, angiotensin II has also been shown to stimulate MCP-1 and VCAM -1 expression in rat aorta [97] and elevate LOX-1 expression in cultured vascular endothelial cells [98]. Interestingly, homoctysteine as mentioned above induces the expression of MCP-1, VCAM-1 and LOX-1 [77,85]. Thus, elevated levels of homocysteine may lead to hypertension by mechanisms similar to that of angiotensin II. This hypothesis is further supported by the report that methionine loading in normotensive and spontaneously hypertensive rats resulted in quantitative difference in homocysteine in the two rats. In spontaneously hypertensive rat, the serum levels of homocysteine were higher than in normotensive rats. Furthermore, methioninerelated aortic alterations developed earlier were considerably more pronounced with the formation of additional connective tissue in spontaneously hypertensive rats [99]. Interestingly, administration of angiotensin II exacerbated the methionine loading-related aortic alterations. Mild hyperhomocysteinemia is associated with stiffer small arteries with increased collagen deposition but these changes are accentuated by angiotensin II-induced blood pressure elevation [100]. There is also a report, which suggests that in NIH/3T3 fibroblasts, angiotensin II induces GATA4 activity and homocysteine delayed this binding and hence alters the angiotensin II signaling [101]. It is thus perceived that the deleterious effects of homocysteine may at least in part be mediated via modulation of angiotensin II -signaling for gene transcription.

\section{vi) Homocysteine and extra cellular matrix}

Homocysteine up regulates the synthesis and accumulation of SMC collagen [[102] Figure 5, branch 2] and several studies have demonstrated that homocysteine is mitogenic for arterial SMCs [103,104] Extra-cellular matrix proteins like collagen are known to be critical components of atherosclerotic lesions [105]. The proliferation of smooth muscle cells and synthesis of extracellular matrix are important determinants of the extent of lesion development and plaque stability. Fibrillar collagen has an important role in the pathogenesis of atherosclerosis due to its substantial contribution to the mass of connective tissue. It renders structural support for the plaques [106]. Uncontrolled collagen accumulation leads to arterial stenosis, while excessive collagen breakdown combined with inadequate synthesis weakens plaques thereby making them prone to rupture.

Apart from collagen, homocysteine induces matrix metalloproteinases. Remodeling of extra-cellular matrix of the arterial wall by inducing elastolysis via activation of metalloproteinases in response to elevated levels of homocysteine is shown by studies in animal models. Chaussalet et al [107] showed that pathological levels of homocysteine increased the secretion of elastolytic metalloproteinase-2 and -9 and their activator kallikrein, in HUVECs [107]. Furthermore, hyperhomocysteinemic patients had elevated mRNA levels of MMP-9 and tissue inhibitors of metalloproteinases-1 (TIMP-1) in freshly isolated peripheral blood mononuclear cells (PBMCs). Most importantly 
Table 4: An exhaustive list of Gene polymorphism studies that have reported to affects the plasma level of homocysteine

\begin{tabular}{|c|c|c|c|c|c|}
\hline \multirow[t]{2}{*}{ S.NO } & \multirow[t]{2}{*}{ Gene Symbol } & \multirow[t]{2}{*}{ Polymorphism } & \multirow[t]{2}{*}{ Amino Acid } & \multicolumn{2}{|r|}{ Consequences } \\
\hline & & & & $\begin{array}{c}\text { Homocysteine } \\
\text { Level }\end{array}$ & $\begin{array}{c}\text { Gene expression /Enzyme } \\
\text { Activity }\end{array}$ \\
\hline I & MTHFR & $\begin{array}{l}\text { C677T } \\
\text { Al298C } \\
\text { Al793G }\end{array}$ & $\begin{array}{l}\text { A222V } \\
\text { E429 A } \\
\text { R594Q }\end{array}$ & $\begin{array}{l}\uparrow \\
\uparrow \\
\uparrow *\end{array}$ & $\begin{array}{l}\downarrow[140] \\
\downarrow \\
\text { N.R }\end{array}$ \\
\hline 2 & CBS & $\begin{array}{l}31 \text { bp VNTR (exon I3-intron 13) } \\
\text { G919A } \\
844 \text { Ins } 68 \text { (Exon 8) } \\
\text { T833C }\end{array}$ & $\begin{array}{l}-\overline{--} \\
\text { G307S } \\
-\bar{L} 278 \mathrm{~T}\end{array}$ & $\begin{array}{l}\uparrow * *[14|-| 42] \\
\uparrow[143-144] \\
\downarrow[12 \mid] \\
\uparrow[120]\end{array}$ & $\begin{array}{l}\downarrow \\
?[120] \\
\uparrow(P)[145] \\
?[120]\end{array}$ \\
\hline 3 & MTR & A2756G & D919G & $\downarrow[12 \mid]$ & N.R \\
\hline 4 & MTRR & A66G & I22M & $\uparrow[145]$ & N.R \\
\hline 5 & MAT & G79IA & $\mathrm{R} 264 \mathrm{H}$ & NE $[146]$ & $\downarrow[147]$ \\
\hline 6 & TYMS & $\begin{array}{l}\text { A 28-bp repeat (Enhancer region) } \\
\text { A 6-bp deletion (3'UTR) }\end{array}$ & ------ & $\begin{array}{l}\uparrow[124, \mid 25] \\
\downarrow(\mathrm{del} / \mathrm{del})[148]\end{array}$ & $\begin{array}{l}\text { Alteration in transcription level[ }[120] \\
\downarrow[149]\end{array}$ \\
\hline 7 & СTH & GI346T & S403I & $\uparrow[126]$ & N.R \\
\hline 8 & GCP II/Folh I & $\mathrm{CI} 56 \mathrm{IT}$ & $\mathrm{H} 475 \mathrm{Y}$ & $\uparrow[127,128]$ & $\downarrow[128]$ \\
\hline 9 & RFC-I & G80A & $\mathrm{R} 26 \mathrm{H}$ & NE [129] & N.R \\
\hline 10 & eNOS & $\begin{array}{l}\text { G894T } \\
\text { T786C (Promoter) } \\
\text { CA Repeats (Intron 13) }\end{array}$ & \begin{tabular}{l} 
E298D \\
\hdashline----- \\
-----
\end{tabular} & $\begin{array}{l}\uparrow[150] \\
\uparrow[152] \\
\uparrow(\text { In female) [154] }\end{array}$ & $\begin{array}{l}\text { N.E }[151] \\
\downarrow[153] \\
\text { N.R }\end{array}$ \\
\hline 11 & TC II & $\begin{array}{l}\text { C776G } \\
\text { A67G }\end{array}$ & $\begin{array}{l}\mathrm{P} 259 \mathrm{R} \\
123 \mathrm{~V}\end{array}$ & $\begin{array}{l}\uparrow[130] \\
\downarrow[130]\end{array}$ & $\downarrow[155]$ \\
\hline 12 & APO E & Epsilon4 alleles & ------ & $\uparrow[156]$ & N.R \\
\hline 13 & PAI-I & 4G Ins/del (Promoter) & ------- & $\uparrow[157]$ & $\begin{array}{l}\text { Affects the response of the PAI-I } \\
\text { promoter to cytokines [158] }\end{array}$ \\
\hline 14 & F2 & G202I0A (3'UTR) & -------- & $\uparrow[159]$ & $\uparrow[160]$ \\
\hline 15 & Factor $\mathrm{V}$ & GI69IA & R506Q & $\uparrow[159]$ & $\begin{array}{l}\text { Impairs APC mediated inactivation of } \\
\text { factor } \mathrm{Va}[161]\end{array}$ \\
\hline
\end{tabular}

N.R Not reported in the literature

N.E No Effect was observed.

* Border line association was observed in the presence of high folate concentration.

** After post methionine load

(P) Presence of low concentration of pyridoxal -5-phosphate.

folic acid treatment reduced the levels of homocysteine and concomitantly a significant reduction in the levels of MMP-9 and TIMP-1 mRNA in PBMCs was observed [108].

\section{Hyperhomocysteinemia: Neurological disorders}

Elevated levels of homocysteine have been associated with Alzheimer disease (Figure 7). A characteristic feature of the disease is the accumulation of amyloid beta $(\mathrm{A} \beta)$ peptide and formation of Amyloid plaques and neurofibrillary tangles in the brain. Although the mechanism of neurodegeneration has not yet been completely elucidated, it is reported that increased calcium levels in the cytosol, increased generation of reactive oxygen species, hyper phosphorylation of tau proteins and apoptosis are the important hallmarks of this disease $[109,110]$. Increased surface phosphatidyl serine (PS) is an early marker of neuronal apoptosis [111]. The involvement of reactive oxygen species is supported by the fact that high concentrations of copper have been found in the vicinity of $A \beta$ amyloid deposits [112]. Moreover, high levels of antioxidant enzyme such as heme oxygenase-1, SOD-1, catalase and GPX were observed in plaque of brain tissue. Homocysteine also increases the levels of calcium and is known to generate reactive oxygen species especially in the presence of transition metal ions and thus it is not surprising that $\mathrm{AD}$ patients show elevated levels of homocysteine. Seshadri et al. found elevated levels of homocysteine prior to disease onset and suggested that the risk of $\mathrm{AD}$ increases by about $40 \%$ for every $5 \mu \mathrm{M}$ increase in the concentration of homocysteine [113].

$\mathrm{AD}$ patients have elevated levels of homocysteine and decreased levels of SAM. This is believed to alter the DNA methylation status and hence gene expression in $\mathrm{AD}$ patients. This hypothesis is supported by the observation that SAM when added to human neuroblastoma SK-N-SH cells in culture, down-regulates expression of PS I gene coding for presenilin, a key factor for $A \beta$ formation in $A D$ due to methylation of its promoter [114]. Similarly, there are other studies suggesting that levels of SAM, folate and vitamin B12 influence DNA methylation of the genes that are involved in the $A \beta$ formation [115]. Furthermore, it 
has also been reported that Herp, a homocysteine responsive protein, up regulated during ER stress, regulates PSmediated amyloid beta generation presumably by binding to PS [116].

Homocysteine acts as an agonist and a partial antagonist at the glutamate binding site of the NMDA and the glycine-binding site of the receptor respectively. Under physiological conditions, when the concentration of glycine is normal, the neurotoxicity of homocysteine is observed at a very high concentration (millimolar range). However, under pathological conditions, such as in stroke or trauma where glycine levels in the brain is elevated, neurotoxicity of homocysteine is observed even at very low concentrations of homocysteine $(10-100 \mu \mathrm{M})$ as the neurotoxic attributes of homocysteine exceeds its protective activity [117]. Under physiological conditions excitation of glutamate receptors initiates the stimulation of lipases and phospholipases with the generation of second messengers that are necessary for normal cell function. However, over stimulation of glutamate receptors leads to excessive calcium entry, abnormal phosphorylation and proteolysis. Thus, increase in the concentration of homocysteine probably results in the over stimulation of glutamate receptors resulting in increased calcium influx. The neuronal damage is due to excess calcium influx and also the accumulation of reactive oxygen species.

Thus, we propose that homocysteine either by inducing oxidative stress or ER stress might lead to apoptosis which in turn may result in neurological disorders. Alternatively homocysteine might act on glutamate receptors triggering a cascade of events that might result in the disease.

\section{Polymorphisms in genes resulting in hyperhomocysteinemia}

Quantitative differences in the activity and availability of enzymes involved in regulation of homocysteine levels directly or indirectly are important in regulating the levels of homocysteine and hence phenotype of complex diseases. The factors that contribute to quantitative variation between individuals are repeat and single nucleotide polymorphism at the genetic level and epigenetic modifications. There are several attempts to analyze polymorphism in genes related to homocysteine pathway. A similar analysis of polymorphism in genes that are part of the interlinked network would be necessary to understand the implications of plasma homocysteine levels on predisposition and manifestation of complex diseases.

Polymorphisms in the genes involved in the methionine and the folate cycles and the transsulfuration pathway (Figure 1) are correlated with elevation of homocysteine levels. A list of genes relevant to homocysteine metabolism along with the known polymorphism and its effect on homocysteine level has been listed (Table 4). Among the genetic polymorphisms MTHFR C677T has been studied extensively. Along with C677T, the 1298A>C and $1793 \mathrm{G}>\mathrm{A}$ polymorphism were associated with the plasma total homocysteine, folate, and vitamin B12 in kidney transplant recipients [118]. In a recent study we found that in the Indian population MTHFR A1298C but not C677T polymorphism was associated with plasma homocysteine levels [119]. Cystathionine $\beta$-synthase (CBS), the first enzyme in transsulfuration pathway, is a B6 dependent heme protein in mammals. Common mutations in the gene (G919A and T833C) lead to hyperhomocysteinemia, which is directly associated with increased risk of cerebral thrombosis [120]. Furthermore, the most prevalent mutations, a $68 \mathrm{bp}$ insertion in the CBS gene leads to lower increase in post methionine load homocysteine levels while A2756G transition in MS (MTR) gene, are associated with decreased fasting levels of plasma homocysteine [121]. Methionine is converted to SAM by the enzyme methionine-adenosyl transferase (MAT). There are reports suggesting that the expression of MAT is altered in alcoholic liver injury [122]. A tandem repeat polymorphism with the gene coding for thymidylate synthase (TYMS) is known to affect the expression of this enzyme [123]. Reports suggest that TYMS 3/3 genotype is associated with reduced plasma folate and among individuals with low dietary folate intake is associated with elevated plasma homocysteine levels. But the TYMS 3R3R genotype is not a determinant of homocysteine in healthy young Caucasian adults from Northern Ireland $[124,125]$. There is also an association of a common nonsynonymous SNP in the cystathionase (CTH) gene G1346T (S403I) with plasma homocysteine concentrations [126]. Apart from these, glutamate carboxypeptidase II (GCPII) polymorphism (H475Y) is known to elevate the levels of homocysteine/ folate in plasma $[127,128]$.

Trascobalamin II (TCN II) facilitates the transport of the vitamin B12 to various tissues. Genetic variations in TCNII gene such as Pro259Arg significantly decrease holoTCNII or holo-TCNII concentrations [129]. Karin et al have mentioned that cardiovascular disease patients and normal controls, who have high vitamin B12 (>299 $\mathrm{pmol} / \mathrm{L})$, tHcy concentrations are lower in individuals homozygous for occurrence of proline259 (259PP) in TCNII protein compared to those with 259PR and 259RR. Therefore, 259PP individuals may be more susceptible to reduction of plasma tHcy in response to increase in vitamin B12 levels [130].

Polymorphism in genes is population dependent. Thus, it might be important to study the status of all these polymorphism in different cohorts to evaluate the importance of each of these polymorphisms with respect to hyperhomocysteinemia. 


\section{Conclusion}

The challenges of understanding the molecular etiology of complex diseases is in designing a comprehensive analysis of genetic and epigenetic factors that contribute to quantitative differences in the levels of proteins coded by genes in pathways relevant the disease phenotype. The source of data to derive a rational list of genes for analysis is the literature where interactions and functional relationships between individual gene products have been elucidated. The present study is aimed at generating a resource for selection of genes for polymorphism screening and analysis of mutations as well as epigenetic modification in relation to hyperhomocysteinemia.

We have compiled a gene-list for researchers interested in deciphering the molecular basis of the role of homocysteine as an independent risk factor in cardiovascular diseases and other complex diseases. Among the variety of pathways that are modulated directly or indirectly by the levels of homocysteine, endoplasmic reticulum stress or ER stress emerges as a common pathway affecting different complex diseases. The data compiled here would assist the selection of genes for analysis based on the disease of interest and/or pathways of interest. Presently we are using the gene list for population specific frequency of known SNP and for discovery of new SNP.

It is noted that the levels of Homocysteine may be closely linked to epigenetic effects both as post-replication and post-translation modification. Methylation of histones plays an important role in chromatin remodeling and maintenance of the remodeled state through mitosis. With reference to post-replication modification of CpG sequences homocysteine pathway can function as a autoregulatory process with reference to methylation of 5 'upstream sequences of genes central to its own metabolism: while it can also influence the expression of other genes by regulation of levels of SAM for methylation of 5' upstream sequences. Thus a pathway related analysis of SNP as well as variation at epigenetic level is necessary for complete understanding of the molecular mechanisms relating homocysteine levels and complex disorders.

\section{List of abbreviations}

B2: Vitamin B2 ; B12: Vitamin B12; 5f-THF:5-formyltetrahydrofolate; 5,10-CH2-THF: 5,10-methylenetetrahydrofolate; 5-CH3THF: 5-methyltetrahydrofolate; dUMP: Uridine -5-prime monophosphate; dUTMP: Tymidine -5prime monophosphate; DMG: Dimethylglycine; DMGDH: Dimethylglycine Dehydrogenase; $M^{+}$: Metal catalysed; ERKP: Phophorylation of Extracellular signal regulated kinase; $e I F-2 \alpha$ : Eukaryote initiation factor $2 \alpha$; CHOP : C/EBP-homologous protein; PERK: PKR-like endoplasmic reticulum eIF2alpha kinase; CEBPB: CCAAT/ enhancer -binding protein alpha; EGR1: Early growth response 1;CCND1: Cyclin D1; IL6R: Interleukin 6 receptor; LEP: Leptin; LEPR: Leptin receptor; PTX3: Pentraxin 3; STAT3: Signal Transducer And Activator Of Transcription 3 TNFRSF1B: Tumor Necrosis Factor Receptor Member 1A; PLA2: Phospholipase A2; LOX: Lipoxygenase; COX; Cycloxygenase; PS: Phosphatidyl Serine; PARP; Poly-ADPribosome polymerase

\section{Acknowledgements}

The study was supported in part by funds provided by the Department of Biotechnology, Govt. of India (SS and VB) under project BT/PR4525/Med/ 14/533/2003. The authors are grateful to Dr. Dwaipayan Bharadwaj and Mythily Ganapathi for critically evaluating the manuscript. P S is grateful to the University Grant Commission and AM and AS to the Council of Scientific and Industrial Research (CSIR) for Junior Research Fellowship. SK is grateful to CSIR for his fellowship.

\section{References}

I. Eikelboom JW, Lonn E, Genest J Jr, Hankey G, Yusuf S: Homocyst(e)ine and cardiovascular disease: a critical review of the epidemiologic evidence. Ann Intern Med 1999, 13 I:363-3.

2. McCully KS: Vascular pathology of homocystinemia: Implication for the arteriosclerosis. Am J Pathology 1969, 56: I II-I 28.

3. Clarke R, Smith $A D$, Jobst KA, Refsum $H$, Sutton $L$, Ueland PM: Folate, vitamin $B I 2$, and serum total homocysteine levels in confirmed Alzheimer disease. Arch Neurol 1998, 55: I449- I 455.

4. Mills JL, McPartlin JM, Kirke PN, Lee YJ, Conley MR, Weir DG, Scott JM: Homocysteine metabolism in pregnancies complicated by neural-tube defects. Lancet 1995, 345: I49-I5I.

5. Applebaum J, Shimon H, Sela BA, Belmaker RH, Levine J: Homocysteine levels in newly admitted schizophrenic patients. J Psychiatr Res 2004, 38:413-4I6.

6. Van GC, Stehouwer CD: Homocysteine metabolism in renal disease. Clin Chem Lab Med 2003, 41:1412-1417.

7. Villadsen MM, Bunger MH, Carstens M, Stenkjaer L, Langdahl BL: Methylenetetrahydrofolate reductase (MTHFR) C677T polymorphism is associated with osteoporotic vertebral fractures, but is a weak predictor of BMD. Osteoporos Int 2005, 16:4II-4I6.

8. De Luis DA, Fernandez N, Arranz ML, Aller R, Izaola O, Romero E: Total homocysteine levels relation with chronic complications of diabetes, body composition, and other cardiovascular risk factors in a population of patients with diabetes mellitus type 2. J. Diabetes Compl 2005, 19:42-46.

9. Rudy A, Kowalska I, Straczkowski M, Kinalska I: Homocysteine concentrations and vascular complications in patients with type 2 diabetes. Diabetes Metab 2005, 31:I I 2-I I 7.

10. Mansoor MA, Bergmark C, Svardal AM, Lønning PE, Ueland PM: Redox Status and Protein Binding of Plasma Homocysteine and Other Aminothiols in Patients with Early-Onset Peripheral Vascular Disease Homocysteine and Peripheral Vascular Disease. Arterioscl Thromb Vasc Biol 1995, 15:232-240.

II. Castro R, Rivera I, Martins C, Struys EA, Jansen EE, Clode N, Graca LM, Blom H], Jakobs C, Tavares de Almeida I: Intracellular S-adenosylhomocysteine increased levels are associated with DNA hypomethylation in HUVEC. J Mol Med 2005 in press.

12. Hoffman DR, Marion DW, Cornatzer WE, Duerre JA: S-Adenosylmethionine and S-Adenosylhomocysteine Metabolism in isolated Rat Liver. J Biol Chem 1980, 255:10822-10827.

13. Yi P, Melnyk S, Pogribna M, Pogribny IP, Hine RJ, James SJ: Increase in Plasma Homocysteine Associated with Paralle Increases in Plasma S-Adenosylhomocysteine and Lymphocyte DNA Hypomethylation. J Biol Chem 2000, 275:29318-29323.

14. Li H, Goligorsky MS: Endothelial Gene Responses to Homocysteine: Relation to Atherosclerosis. Exp Nephrol 2002, 10:164-169.

15. Starkebaum G, Harlan JM: Endothelial Cell Injury Due to Copper-catalyzed Hydrogen Peroxide Generation from Homocysteine. J Clin Invest 1986, 77: I370-I 376.

16. Sengupta S, Wehbe C, Majors AK, Ketterer ME, DiBello PM, Jacobsen DW: Relative Roles of Albumin and Ceruloplasmin in the 
Formation of Homocystine, Homocysteine- Cysteine-mixed Disulfide, and Cystine in Circulation. J Biol Chem 200I, 276:46896-46904

17. Jacobsen DW: Hyperhomocysteinemia and oxidative stress: Time for a Reality Check? Arteriosd Thromb Vasc Biol 2000, 20:1182-1184

18. Handy DE, Zhang, Loscalzo J: Homocysteine downregulates cellular glutathione peroxidase (GPXI) by decreasing translation. J Biol Chem 2005, 280: I5518-15525.

19. Upchurch GR Jr, Welch GN, Fabian AJ, Freedman JE, Johnson JL, Keaney JF Jr, Loscalzo J: Homocyst(e)ine Decreases Bioavailable Nitric Oxide by a Mechanism Involving Glutathione Peroxidase. J Biol Chem 1997, 272: I70I2-I70I.

20. Weiss N, Zhang YY, Heydrick S, Bierl C, Loscalzo J: Overexpression of cellular glutathione peroxidase rescues homocyst(e)ine induced endothelial dysfunction. Proc Natl Acad SciU SA 200I, 98: I2503-I 2508 .

21. Nonaka H, Takeshi T, Watari Y, Emoto N, Yokoyama M: Taurine Prevents the Decrease in Expression and Secretion of Extracellular Superoxide Dismutaselnduced byHomocysteine. Circulation 200I, 104: I I65-II70.

22. Avila MA, Carretero MV, Rodriguez EN, Mato JM: Regulation of hypoxia of MAT activity \& gene expression in rat hepatocytes. Gastroent 1998, II4:364-71.

23. Tawakol A, Omland T, Gerhard M, Wu JT, Creager MA: Hyperhomocyst(e)inemia is Associated With Impaired EndotheliumDependent Vasodilation in Humans. Circulation 1997, 95:III9-II2I.

24. Eberhardt RT, Forgione MA, Cap A, Leopold JA, Rudd MA, Trolliet M, Heydrick S, Stark R, Klings ES, Moldovan NI, Yaghoubi M, Goldschmidt-Clermont PJ, Farber HW, Cohen R, Loscalzo J: Endothelial dysfunction in a murine model of mild hyperhomocyst (e) inemia. J Clin Invest 2000, 106:483-49I.

25. Stamler JS, Singel DJ, Loscalzo !: Biochemistry of nitric oxide and its redox-activated forms. Science 1992, 258:1898-902.

26. Stamler JS, Simon DI, Osborne JA, Mullins ME, Jaraki O, Michel T, Singel DJ, Loscalzo J: S-Nitrosylation of proteins with nitric oxide: Synthesis and characterization of biologically active compounds. Proc Natl Acad Sci U S A 1992, 89:444-448.

27. Gryglewski RJ, Palmer RM, Moncada S: Superoxide anion is involved in the breakdown of endothelium-derived vascular relaxing factor. Nature 1986, 320:454-456.

28. Kuzkaya N, Weissmann N, Harrison DG, Dikalov S: Interactions of peroxynitrite, tetrahydrobiopterin, ascorbic acid, and thiols: implications for uncouplingendothelial nitric-oxide synthase. J Biol Chem 2003, 278:22546-54.

29. Topal G, Brunet A, Millanvoye E, Boucher JL, Rendu F, Devynck MA, David-Dufilho M: Homocysteine induces oxidative stress by uncoupling of no synthase activity through reduction of tetrahydrobiopterin. Free Rad Biol \& Med 2004, 36:|1532-I54I.

30. Boger RH, Bode-Boger SM, Szuba A, Tsao PS, Chan JR, Tangphao O, Blaschke TF, Cooke JP: Asymmetric Dimethylarginine (ADMA): A Novel Risk Factor for Endothelial Dysfunction its Role in Hypercholesterolemia. Circulation 1998, 98: |842-1847.

31. Ghosh SK, Paik WK, Kim S: Purification and molecular identification of two protein methylases I from calf brain. Myelin basic protein- and histone-specific enzyme. J Biol Chem 1989, 264: 19024-19033.

32. Lentz SR, Rodionov RN, Dayal S: Hyperhomocysteinemia, endothelial dysfunction, and cardiovascular risk: the potential role of ADMA. Atherosclerosis 2003, 4(Supplements):6I-65.

33. Selley ML: Increased concentrations of homocysteine and asymmetric dimethylarginine and decreased concentrations of nitric oxide in the plasma of patients with Alzheimer's disease. Neurobio Of Aging 2003, 24:903-907.

34. Cai H, Li Z, Goette A, Mera F, Honeycutt C, Feterik K, Wilcox JN, Dudley SC Jr, Harrison DG, Langberg J]: Downregulation of endocardial nitric oxide synthase expression and nitric oxide production in atrial fibrillation: potential mechanisms for atrial thrombosis and stroke. Circulation 2002, 106:2854-8.

35. Kaufman RJ: Stress signaling from the lumen of the endoplasmic reticulum coordination of gene transcriptional and translational controls. Genes \& Development 1999, 13:12 |1-1233.

36. Randal J Kaufman : Orchestrating the unfolded protein response in health and disease. / Clin Invest 2002, I I 0: I 389- 1398.
37. Outinen PA, Sood SK, Liaw PC, Sarge KD, Maeda N, Hirsh J, Ribau J, Podor TJ, Weitz Jl, Austin RC: Characterization of the stressinducing effects of homocysteine. Biochem J 1998, 332: | | -22I.

38. Outinen PA, Sood SK, Pfeifer SI, Pamidi S, Podor TJ, Li J, Weitz J: Homocysteine-Induced Endoplasmic Reticulum Stress and Growth Arrest Leads to Specific Changes in Gene Expression in Human Vascular Endothelial Cells. Blood 1999, 94:959-967.

39. Kokame K, Kato H, Miyata T: Homocysteine-respondent Genes in Vascular Endothelial Cells Identified by Differential Display Analysis. J Biol Chem 1996, 27 I:29659-29665.

40. Kokame K, Agarwala KL, Kato H, Miyata T: Herp, a New Ubiquitin-like Membrane Protein Induced by Endoplasmic Reticulum Stress. J Biol Chem 2000, 275:32846-32853.

41. Price BD, Calderwood SK: Gadd45 and Gadd 153 messenger RNA levels are increased during hypoxia and after exposure of cells to agents which elevate the levels of the glucose-regulated proteins. Cancer Res 1992, 52:38I4-38I7.

42. Austen M, Cerni C, Henriksson M, Hilfenhaus S, Luscher Firzlaff JM, Menkel A, Seelos C, Sommer A, Luscher B: Regulation of cell growth by the Myc-Max-Mad network: role of Mad proteins and YYI. Curr Top Micro Immunol 1997, 224: I23-30.

43. Galvin KM, Shi Y: Multiple Mechanisms of Transcriptional Repression by YYI. Mol and Cell Biol 1997, 17:3723-3732.

44. Yoneda T, Imaizumi K, Ono K, Yui D, Gomi F, Katayama T, Tohyama M: Activation of Caspase- I 2, an Endoplastic Reticulum (ER) ResidentCaspase, through Tumor Necrosis Factor Receptor-associated Factor 2-dependent Mechanism in Response to the ER Stress. J Biol Chem 200I, 276:13935-13940.

45. Zhang C, Kawauchi J, Adachi MT, Hashimoto Y, Oshiro S, Aso T, Kitajima S: Activation of JNK and Transcriptional Repressor ATF3/LRFI through the IREI/TRAF2 Pathway Is Implicated in Human Vascular Endothelial Cell Death by Homocysteine. Biochem Biophys Res Commun 200I, 289:718-724.

46. Gross A, Yin XM, Wang K, Wei MC, Jockel J, Milliman C, Erdjument Bromage H, Tempst P, Korsmeyer SJ: Caspase Cleaved BID Targets Mitochondria and is Required for Cytochrome $C$ Release, while BCL-XL Prevents This Release but Not Tumor Necrosis Factor-RI/Fas Death. J Biol Chem 1999, 274: II56-II63.

47. Dong F, Zhang X, Li SY, Zhang Z, Ren Q, Culver B, Ren J: Possible Involvement of NADPH Oxidase and JNK in HomocysteineInduced Oxidative Stress and Apoptosis in Human Umbilical Vein Endothelial Cells. Cardiovasc Toxicol 2005, 5:9-20.

48. Kramer K, Harrington EO, Lu O, Bellas R, Newton J, Sheahan KL, Rounds S: Isoprenylcysteine Carboxyl Methyltransferase Activity Modulates Endothelial Cell Apoptosis. Mol Biol Cell 2003, I 4:848-857.

49. Wang H, Yoshizumi M, Lai K, Tsai JC, Perrella MA, Haber E, Lee ME: Inhibition of Growth and p2|ras Methylation in Vascular Endothelial Cells by Homocysteine but Not Cysteine. J Biol Chem 1997, 272:25380-25385.

50. Kim IK, Copeland RL Jr, Lee JH, Kim HS, Asafo Adjei E, Brown ND, Estrada JS, Gordon RK, Garcia GE, Chiang PK: Induction of Apoptosis and c-myc in LI210 Lymphocytic Leukemia Cells by Adenosine. J Biomed Sci 1994, 3:154-157.

5I. Juin P, Hueber AO, Littlewood T, Evan G: c-Myc-induced sensitization to apoptosis is mediated through cytochrome c release. Genes Dev 1999, I3:|367-8I.

52. Klefstrom J, Verschuren EW, Evan G: c-Myc Augments the Apoptotic Activity of Cytosolic Death Receptor Signaling Proteins by Engaging the Mitochondrial Apoptotic Pathway. J Biol Chem 2002, 277:43224-43232.

53. Lee SJ, Kim KM, Namkoong S, Kim CK, Kang YC, Lee H, Ha KS, Han JA, Chung HT, Kwon YG, Kim YM: Nitric oxide inhibition of homocysteine-induced human endothelial cell apoptosis by down-regulation of p53-dependent Noxa expression through the formation of S-nitrosohomocysteine. J Biol Chem 2005, 280:578I-5788

54. Chuikov S, Kurash JK, Wilson JR, Xiao B, Justin N, Ivanov GS, McKinney K, Tempst P, Prives C, Gamblin SJ, Barlev NA, Reinberg D: Regulation of p53 activity through lysine Methylation. Nature 2004, 432:353-360.

55. Hirao A, Kong YY, Matsuoka S, Wakeham A, Ruland J, Yoshida H, Liu D, Elledge S], Mak TW: DNA Damage-Induced Activation of 
p53 by the Checkpoint Kinase Chk2. Science 2000, 287: $1824-1827$

56. Suzuki YJ, Lorenzi MV, Shi SS, Day RM, Blumberg JB: Homocysteine exerts cell type-specific inhibition of AP-I transcriptionfactor. Free Rad Biol \& Med 2000, 28:39-45.

57. Ingram AJ, Krepinsky JC, James L, Austin RC, Tang D, Salapatek AM, Thai K, Scholey JW: Activation of mesangial cell MAPK in response to homocysteine. Kidney Intern 2004, 66:733-745.

58. Roybal CN, Yang S, Sun CW, Hurtado D, Vander Jagt DL, Townes TM, Abcouwer SF: Homocysteine Increases the Expression of Vascular Endothelial Growth Factor by a Mechanism Involving Endoplasmic Reticulum Stress and Transcription Factor ATF4. J Biol Chem 2004, 279: I 4844-I 4852.

59. Matsumoto $T$, Claesson-Welsh L: VEGF receptor signal transduction. SCi STKE 200I, I I 2:RE2I.

60. Werstuck GH, Lentz SR, Dayal S, Hossain GS, Sood SK, Shi YY, Zhou J, Maeda N, Krisans SK, Malinow MR, Austin RC: Homocysteineinduced endoplasmic reticulum stress causes dysregulation of the cholesterol and triglyceride biosynthetic pathways. J Clin Invest 200I, 107:1263-1273.

61. Ji C, Kaplowitz N: Hyperhomocysteinemia, endoplasmic reticulum stress, and alcoholic liver injury. World J Gastroenterol 2004, I 0:1699-1708.

62. Majors AK, Sengupta S, Willard B, Kinter MT, Pyeritz RE, Jaocbsen DW: Homocysteine Binds to Human Plasma Fibronectin and Inhibits Its Interaction With Fibrin. Atherosd Thromb Vasc Biol 2002, 22:1354-1359.

63. Undas A, Williams EB, Butenas S, Orfeo T, Mann KG: Homocysteine Inhibits Inactivation of Factor Va by Activated Protein C. J Biol Chem 200I, 276:4389-4397.

64. Hajjar KA: Homocysteine-induced Modulation of Tissue Plasminogen Activator Binding to Its Endothelial Cell Membrane Receptor. J Clin Invest 1993, 91 :2873-2879.

65. Fryer RH, Wilson BD, Gubler DB, Fitzgerald LA, Rodgers GM: Homocysteine, a risk factor for premature vascular disease and thrombosis, induces tissue factor activity in endothelial scells. Arterioscler Thromb 1993, 13:1327-1333.

66. Hayashi T, Honda G, Suzuki K: An Atherogenic Stimulus Homocysteine Inhibits Cofactor Activity of Thrombomodulin and Enhances Thrombomodulin Expression in Human Umbilical Vein Endothelial Cells. Blood 1992, 79:2930-2936.

67. Nishinaga M, Ozawa T, Shimada K: Homocysteine, a Thrombogenic Agent, Suppresses Anticoagulant Heparan Sulfate Expression in Cultured Porcine Aortic Endothelial Cells. J Clin Invest 1993, 92: I 38I- I386.

68. Ross R: Atherosclerosis-An Inflammatory Disease. N Engla J Med 1999, 340: II5-126.

69. Li H, Lewis A, Brodsky S, Rieger R, Iden C, Goligorsky MS: Homocysteine Induces 3- Hydroxy-3- Methylglutaryl Coenzyme A Reductase in Vascular Endothelial Cells. Circulation 2002, 105: 1037-1043.

70. Woo CW, Siow YL, Pierce GN, Choy PC, Minuk GY, Mymin D, O K: Hyperhomocysteinemia Induces Hepatic Cholesterol Biosynthesis and Lipid Accumulation via Activation of Transcription Factors. Am J Physiol Endocrinol Metab 2005, 288: EI002-10.

7I. Geoff Werstuck H, Steven Lentz R, Sanjana Dayal, Gazi Hossain S, Sudesh Sood K, Yuan Shi Y, Ji Zhou, Nobuyo Maeda, Skaidrite Krisans K, Rene Malinow M, Richard Austin C: Homocysteine-induced endoplasmic reticulum stress causes dysregulation of the cholesterol and triglyceride biosynthetic pathways. J Clin Invest 200I, 107:1263-127.

72. Beauchamp MC, Renier G: Homocysteine Induces Protein Kinase C Activation and Stimulates c-Fos and Lipoprotein Lipase Expression in Macrophages. Diabetes 2002, 5 I:II80-II87

73. Goldberg I: Lipoprotein lipase and lipolysis: central roles in lipoprotein metabolism and atherogenesis. J Lipid Res 1996, 37:693-707.

74. Hunt MJ, Tyagi SC: Peroxisome proliferators compete and ameliorate Hcymediated endocardial endothelial cell activation. Am J Physiol Cell Physiol 2002, 283: Cl073-Cl079.

75. Staels B, Dallongeville J, Auwerx J, Schoonjans K, Leitersdorf E, Fruchart JC: Mechanism of Action of Fibrates on Lipid and Lipoprotein Metabolism. Circulation 1998, 98:2088-2093.
76. Nagase M, Ando K, Nagase T, Kaname S, Sawamura T, Fujita T: Redox-Sensitive Regulation of LOX-I Gene Expression in Vascular Endothelium. Biochem And Biophys I Res Commun 200I, 28I:720-725.

77. Holven KB, Scholz H, Halvorsen B, Aukrust P, Ose L, Nenseter MS: Hyperhomocysteinemic Subjects Have Enhanced Expression of Lectin-Like Oxidized LDL Receptor-I in Mononuclear Cells. J Nutr 2003, 133:3588-3591.

78. Tontonoz P, Nagy L, Alvarez JG, Thomazy VA, Evans RM: PPAR gamma promotes monocyte/macrophage activation and uptake of oxidized LDL. Cell 1988, 93:24I-252.

79. Jiang C, Ting AT, Seed B: PPAR- $\gamma$ agonists inhibit production of monocyte inflammatory cytokines. Nature 1998, 391:82-86.

80. Tsimikas S, Brilakis ES, Miller ER, McConnell JP, Lennon RJ, Kornman KS, Witztum JL, Berger PB: Oxidized Phospholipids, Lp(a) Lipoprotein, and Coronary Artery Disease. N Engl J Med 2005, 353:46-57.

8I. Ricote M, Li AC, Willson TM, Kelly CJ, Glass CK: The peroxisome proliferators activated receptor- $\gamma$ is a negative regulator of macrophage activation. Nature 1998, 391:79-8I.

82. Roth J, Goebeler M, Ludwig S, Wagner L, Kilian K, Sorg C, Harms E, Schulze-Osthoff $\mathrm{K}$, Koch $\mathrm{H}$ : Homocysteine inhibits tumor necrosis factor-induced activation of endothelium via modulation of nuclear factor-kb activity. Biochimica et Biophysica Acta 200I, I 540: I54-165.

83. Kyriakis JM: Life-or-death decisions. Nature 200I, 4| 4:265-266.

84. Wang G, O K: Homocysteine stimulates the expresion of monocyte chemoattractant protein-I receptor (CCR2) in human monocytes: possible involvement of oxygen free radicals. Biochem J 200I, 357:233-240.

85. Zeng X, Dai J, Remick DG, Wang X: Homocysteine Mediated Expression and Secretion of Monocyte Chemoattractant Protein-I and Interleukin-8 in Human Monocytes. Circ Res 2003, 93:3II-320.

86. Maeda M, Yamamoto I, Fujio Y, Azuma J: Homocysteine induces vascular endothelial growth factor expression in differentiated THP-I macrophages. Biochimica et Biophysica Acta 2003, 1623:41-46.

87. Inoue M, Itoh H, Ueda M, Naruko T, Kojima A, Komatsu R, Doi K, Ogawa Y, Tamura N, Takaya K, Igaki T, Yamashita J, Chun TH, Masatsugu K, Becker AE, Nakao K: Vascular endothelial growth factor (VEGF) expression in human coronary atherosclerotic lesions - possible pathophysiological significance of VEGF in progression of atherosclerosis. Circulation 1998, 98:2108-2116.

88. Celletti FL, Waugh JM, Amabile PG, Brendolan A, Hilfiker PR, Dake MD: Vascular endothelial growth factor enhances atherosclerotic plaque progression. Nat Med 200I, 7:425-429.

89. Ridker PM, Hennekens CH, Roitman-Johnson B, Stampfer MJ, Allen J: Plasma concentration of soluble intercellular adhesion molecule $I$ and risks of future myocardial infarction in apparently healthy men. Lancet 1998, 35 I:88-92.

90. Mansoor MA, Seljeflot I, Arnesen H, Knudsen A, Bates CJ, Mishra G, Larsen TW: Endothelial cell adhesion molecules in healthy adults during acute hyperhomocysteinemia and mild hypertriglyceridemia. Clinical Biochemistry 2004, 37:408-4I4.

91. Araki A, Hosoi T, Orimo $\mathrm{H}$, Ito $\mathrm{H}$ : Association of plasma homocysteine with serum interleukin-6 and C-peptide levels in patients with type 2 diabetes. Metabolism 2005, 54:809-8I4.

92. Avila MA, Berasain C, Prieto J, Mato JM, Garcia-Trevijano ER, Corrales FJ: Influence of impaired liver methionine metabolism on the development of vasculardisease and inflammation. Curr Med Chem Cardiovasc Hematol Agents 2005, 3:267-8I.

93. Alexander RW: Theodore Cooper Memorial Lecture. Hypertension and the pathogenesis of artherosclerosis: oxidative stress and the mediatiin of arterial inflammatory response:a new perspective. Hypertension 1995, 25:|55-|6|

94. Muda P, Kampus P, Zilmer M, Ristimae T, Fischer K, Zilmer K, Kairane $C$, Teesalu R: Effect of antihypertensive treatment with candesartan or amlodipine on glutathione and its redox status, homocysteine and vitamin concentrations in patients with essential hypertension. J Hypertens 2005, 23:105-1 I2.

95. Rajagopalan S, Kurz S, Munzel T, Tarpey M, Freeman BA, Griendling KK, Harrison DG: Angiotensin II-mediated Hypertension in the Rat Increases Vascular Superoxide Production via Membrane NADH/NADPH Oxidase Activation. I Clin Invest 1996, 97:1916-1923. 
96. Chen XL, Tummala PE, Olbrych MT, Alexander RW, Medford RM: Angiotensin II Induces Monocyte Chemoattractant ProteinI Gene Expression in Rat Vascular Smooth Muscle Cells. Circ Res 1998, 83:952-959.

97. Ni W, Kitamoto S, Ishibashi M, Usui M, Inoue S, Hiasa K, Zhao Q, Nishida K, Takeshita A, Egashira K: Monocyte chemoattractant protein-I is an essential inflammatory mediator in angiotensin II-induced progression of established atherosclerosis in hypercholesterolemic mice. Arterioscl Thromb Vasc Biol 2004, 24:534-9.

98. Morawietz H, Rueckschloss U, Niemann B, Duerrschmidt N, Galle J, Hakim K, Zerkowski HR, Sawamura T, Holtz J: Angiotensin I Induces LOX-I, the Human Endothelial Receptor for Oxidized Low-Density Lipoprotein. Circulation 1999, 1 00:899-902.

99. Matthias $\mathrm{D}$, Becker $\mathrm{CH}$, Riezler R, Kindling $\mathrm{PH}$ : Homocysteine induced arteriosclerosis-like alterations of the aorta in normotensive and hypertensive rats following application of high doses of methionine. Atherosclerosis 1996, I 22:201-I6.

100. Neves MF, Endemann D, Amiri F, Virdis A, Pu Q, Rozen R, Schiffrin EL: Small artery mechanics in hyperhomocysteinemic mice: effects of angiotensin II. J Hypertens 2004, 22:959-66.

I0I. Suzuki YJ, Shi SS, Blumberg JB: Modulation of angiotensin II signaling for GATA4 activation by homocysteine. Antioxid Redox Signal 1999, I:233-238.

102. Majors A, Ehrhart LA, Pezacka EH: Homocysteine as a Risk Factor for Vascular Disease. Enhanced Collagen Production and Accumulation by Smooth MuscleCells. Arterioscl Thromb Vasc Biol 1997, I 7:2074-208I.

103. Dalton ML, Gadson PF Jr, Wrenn RW, Rosenquist TH: Homocysteine signal cascade: production of phospholipids, activation of protein kinase $C$, and the induction of c-fos and c-myb in smooth muscle cells. FASEB J 1997, I I:703-7III.

104. Tsai JC, Perrella MA, Yoshizumi M, Hsieh CM, Haber E, Schlegel R, Lee ME: Promotion of vascular smooth muscle cell growth by homocysteine: a link to atherosclerosis. Proc Natl Acad Sci USA 1994, $91: 6369-6373$.

105. Rekhter MD: Collagen synthesis in atherosclerosis: too much and not enough. Cardiovasc Res 1999, 41:376-384.

106. Libby P: Molecular Bases of the Acute Coronary Syndromes. Circulation 1995, 91:2844-2850.

107. Chaussalet M, Lamy E, Foucault-Bertaud A, Genovesio C, Sabatier F, Dignat-George F, Charpiot P: Homocysteine modulates the proteolytic potential of human vascular endothelial cells. Biochem And Bioph Res Commun 2004, 3 16:170-176.

108. Holven KB, Halvorsen B, Schulz H, Aukrust P, Ose L, Nenseter MS: Expression of matrixmetalloproteinase-9 in mononuclear cells of hyperhomocysteinaemic subjects. Eur J Clin Invest 2003, 33:555-60.

109. Holscher C: Possible causes of Alzheimer's Disease: Amyloid fragments, free radicals and calcium Homeostasis. Neurobiology of Disease 1998, 5:|29-|4|.

I I0. Ho PI, Ortiz D, Rogers E, Shea TB: Multiple Aspects of Homocysteine neurotoxicity: Glutamate excitotoxicity,kinase Hyperactivation and DNA damage. J Neurosci Res 2002 , 70:694-702.

III. Rimon G, Bazenet CE, Philpott KL, Rubin LL: Increased surface phosphatidylserine is an surface marker of neuronal apoptosis. JNeurosci Res 1997, 48:563-70.

II2. Huang X, Cuajungco MP, Atwood CS, Hartshorn MA, Tyndall JD, Hanson GR, Stokes KC, Leopold M, Multhaup G, Goldstein LE, Scarpa RC, Saunders AJ, Lim J, Moir RD, Glabe C, Bowden EF, Masters CL, Fairlie DP, Tanzi RE, Bush Al: Cu (II) potentiation of alzheimer abeta neurotoxicity correlation with cell-free hydrogen peroxide production and metal reduction. I Biol Chem 1999, 274:37|II-37||6.

I 13. Seshadri S, Beiser A, Selhub J, Jacques PF, Rosenberg IH, D'Agostino $\mathrm{RB}$, Wilson PW, Wolf PA: Plasma homocysteine as a risk factor for dementia and Alzheimer's disease. N Engl J Med 2002, 346:476-483.

I14. Scarpa S, Fuso A, D'Anselmi F, Cavallaro RA: Presenilin I gene silencing by S-adenosylmethionine: a treatment for Alzheimer disease. FEBS Lett 2003, 54 I: |45-|48.

I 15. Fuso A, Seminara L, Cavallaro RA, D'Anselmi F, Scarpa S: S-adenosylmethionine/homocysteine cycle alterations modify DNA methylation status with consequent deregulation of PSI and
BACE and beta-amyloid production. Mol Cell Neurosci 2005 28: $195-204$

I 16. Sai X, Kawamura Y, Kokame K, Yamaguchi H, Shiraishi H, Suzuki R, Suzuki T, Kawaichi M, Miyata T, Kitamura T, De Strooper B, Yanagisawa K, Komano H: Endoplasmic Reticulum Stress-inducible Protein Herp, Enhance Presenilin-mediated Generation of Amyloid $\beta$-Protein. J Biol Chem 2002, 277:129|5-12920.

117. Lipton SA, Kim WK, Choi YB, Kumar S, D'Emilia DM, Rayudu PV, Arnelle DR, Stamler JS: Neurotoxicity associated with dual actions of homocysteine at the $\mathbf{N}$-methyl-D-aspartate receptor. Proc Natl Acad Sci USA 1997, 94:5923-5928.

I 18. Winkelmayer WC, Huber A, Wagner OF, Horl WH, Sunder Plassmann G, Fodinger M: Associations between MTHFR I793G>A and plasma total homocysteine, folate, and vitamin B in kidney transplant recipients. Kidney Int 2005, 67:1980-5.

I 19. Kumar J, Das SK, Sharma P, Karthikeyan G, Ramakrishnan L, Sengupta S: Homocysteine levels are associated with MTHFR A I 298C polymorphism in Indian population. J Hum Genet 2005 in press.

120. Tsai MY, Garg U, Key NS, Hanson NQ, Suh A, Schwichtenberg Knberg : Molecular and biochemical approaches in the identification of heterozygotes for homocystinuria. Atherosclerosis 1996, I32:69-77.

121. Tsai MY, Bignell M, Yang F, Welge BG, Graham KJ, Hanson NQ: Polygenic influence on plasma homocysteine: association of two prevalent mutations, the 844 ins 68 of cystathionine b-synthase and A2756G of methionine synthase, with lowered plasma homocysteine levels. Atherosclerosis 2000, | 49: | 31 - I 37.

122. Finkelstein JD, Cello JP, Kyle WE: Ethanol-induced changes in methionine metabolism in rat liver. Biochem Biophys Res Commun 1974, 2:525-31.

123. Mandola MV, Stoehlmacher J, Muller-Weeks S, Cesarone G, Yu MC Lenz HJ, Ladner RD: A novel single nucleotide polymorphism within the 5' tandem repeat polymorphism of the thymidylate synthase gene abolishes USF-I binding and alters transcriptional activity. Cancer Res 2003, 63:2898-904.

124. Trinh BN, Ong CN, Coetzee GA, Yu MC, Laird PW: Thymidylate synthase: a novel genetic determinant of plasma homocysteine and folate levels. Hum Genet 2002, I I I:299-302.

125. Brown KS, Kluijtmans LA, Young IS, McNulty H, Mitchell LE, Yarnell JW, Woodside JV, Boreham CA, McMaster D, Murray L, Strain J], Whitehead AS: The thymidylatesynthase tandem repeat polymorphism is not associated with homocysteine concentrations in healthy young subjects. Hum Genet 2004, I | 4: | 82-5.

126. Wang J, Huff AM, Spence JD, Hegele RA: Single nucleotide polymorphism in CTH associated with variation in plasma homocysteine concentration. Clin Genet 2004, 65:483-486.

127. Lievers KJ, Kluijtmans LA, Boers GH, Verhoef P, den Heijer M, Trijbels FJ, Blom HJ: Influence of a glutamate carboxypeptidase's II (GCPII) polymorphism (I56/C0/T) on plasma homocysteine, folate and vitamin $B I 2$ levels and its relationship to cardiovascular disease risk. Atherosclerosis 2002, 1 64:269-273.

128. Devlin AM, Ling EH, Peerson JM, Fernando S, Clarke R, Smith AD, Halsted $\mathrm{CH}$ : Glutamate carboxypeptidase II: a polymorphism associated with lower levels of serum folate and hyperhomocysteinemia. Hum Mol Genet 2000, 22:2837-44.

129. Chango A, Emery-Fillon N, de Courcy GP, Lambert D, Pfister M, Rosenblatt DS, Nicolas JP: A Polymorphism (80G->A) in the Reduced Folate Carrier Gene and Its Associations with Folate Status and Homocysteinemia. Mol Genet Metab 2000, 70:310-315

130. Lievers KJ, Afman LA, Kluijtmans LA, Boers GH, Verhoef P, den Heijer M, Trijbels FJ, Blom HJ: Polymorphisms in the Transcobalamin Gene: Association with Plasma Homocysteine in Healthy Individuals and Vascular Disease Patients. Clinical Chemistry 2002, 48: I383-I389.

I31. Garg UC, Hassid A: Nitric Oxide-generating Vasodilators and 8-Bromo-Cyclic Guanosine Monophosphate Inhibit Mitogenesis and Proliferation of Cultured Rat Vascular Smooth Muscle Cells. J Clin Invest 1989, 83: I774-7.

132. Radomski MW, Palmer RM, Moncada S: An L-arginine/nitric oxide pathway present in human platelets regulates aggregation. proc Natl Acad Sci USA 1990, 87:5193-519.

133. De Caterina R, Libby P, Peng HB, Thannickal VJ, Rajavashisth TB, Gimbrone MA Jr, Shin WS, Liao JK: Nitric Oxide Decreases Cytokine-induced Endothelial Activation. J Clin Invest 1995, 96:60-68. 
134. Philip ST, Wang B, Buitrago R, Shy J, Cooke JP: Nitric Oxide Regulates Monocyte Chemotactic Protein-I. Circulation 1997, 96:934-940

135. Peng HB, Libby P, Liao JK: Induction and Stabilization of $\mathbf{I} \kappa \mathbf{B} \alpha$ by Nitric Oxide Mediates Inhibition of NF- $\kappa$ B. J Biol Chem 1995, 270:|42|4-14219.

136. Hogg N, Kalyanaraman B, Joseph J, Struck A, Parthasarathy S: Inhibition of low-density lipoprotein oxidation by nitric oxide Potential role in atherogenesis. FEBS 1993, 334:170-174.

137. Violi F, Marino R, Milite MT, Loffredo L: Nitric oxide and its role in lipid peroxidation. Diabetes Metab Res Rev 1999, I 5:283-8.

138. Rubbo $\mathrm{H}$, Darley Usmar $\mathrm{V}$, Freeman BA: Nitric oxide regulation of tissue free radical injury. Chem Res Toxicol 1996, 95:809-20.

139. Khan BV, Harrison DG, Olbrych MT, Alexander RW, Medford RM Nitric oxide regulates vascular cell adhesion molecule I gene expression and redox-sensitive transcriptional events in human vascular endothelial cells. Proc Natl Acad Sci USA 1996, 93:91|4-9|19.

140. Winkelmayer WC, Huber A, Wagner OF, Horl WH, Sunder Plassmann G, Fodinger M: Associations between MTHFR I793G>A and plasma total homocysteine, folate, and vitamin B in kidney transplant recipients. Kidney Int 2005, 67: 1980-5.

141. Lydia AA, Karin JA, Lievers, Leo AJ, Kluijtmans, Frans Trijbels JM Henk Blo J: Gene-gene interaction between the cystathionine b-synthase 3 I base pair variable number of tandem repeats and the methylenetetrahydrofolate reductase $677 \mathrm{C}>\mathrm{T}$ polymorphism on homocysteine levels and risk for neural tube defects. Mol Genet Metab 2003, 78:2II-2I5.

142. Lievers KJ, Kluijtmans LA, Heil SG, Boers GH, Verhoef P, van Oppenraay-Emmerzaal $D$, den Heijer $M$, Trijbels FJ, Blom HJ: A 31 bp VNTR in the cystathionine beta-synthase (CBS) gene is associated with reduced CBS activity and elevated post-load homocysteine levels. Eur J Hum Genet 200I, 8:583-9.

143. Shao $Y$, Zhang CG, Cui JH: Association of plasma homocysteine and cystathionine beta-synthase polymorphism with cerebral thrombosis. Di Yi Jun Yi Da Xue Xue Bao 2005, 3:35I-3.

144. Dawson PA, Cochran DA, Emmerson BT, Kraus JP, Dudman NP Gordon RB: Variable hyperhomocysteinaemia phenotype in heterozygotes for the Gly307Ser mutation in cystathionine beta- synthase. Aust N Z J Med 1996, 2:180-5.

145. Gaughan DJ, Kluijtmans LA, Barbaux S, McMaster D, Young IS, Yarnell JW, Evans A, Whitehead AS: The methionine synthase reductase (MTRR) A66G polymorphism is a novel genetic determinnt of plasma homocysteine Concentrations. Atherosclerosis 200I, | 57:45 I-456.

146. Chamberlin ME, Ubagai T, Mudd SH, Thomas J, Pao VY, Nguyen TK, Levy HL, Greene C, Freehauf C, Chou JY: Methionine adenosyltransferase I/III deficiency: novel mutations and clinical variations. Am J Hum Genet 2000, 66:347-55.

147. Chamberlin ME, Ubagai T, Mudd SH, Levy HL, Chou JY: Dominant inheritance of isolated hypermethioninemia is associated with a mutation in the human methionine adenosyltransferase IA gene. Am I Hum Genet 1997, 60:540-6.

148. Kealey C, Brown KS, Woodside JV, Young I, Murray L, Boreham CA, McNulty H, Strain JJ, McNulty H, Strain JJ, mCpartin J, Scott JM, Whitehead AS: A common insertion/deletion polymorphism of the thymidylate synthase (TYMS) gene is a determinant of red blood cell folate and homocysteine concentrations. Hum Genet 2005, I I 6:347-53

149. Mandola MV, Stoehlmacher J, Muller Weeks S, Cesarone G, Yu Mc , Lentz HJ, Landner RD: A novel single polymorphism within the 5' tadem repeat polymorphism of the tymidylate synthase gene abolishes USF-I binding and alters transcriptional activity. CancerRes 2003, 63:2898-904.

150. Brown KS, Kluijtmans LA, Young IS, Woodside J, Yarnell JW, McMaster D, Murray L, Evans AE, Boreham CA, McNulty H, Strain J], Mitchell LE, Whitehead AS: Genetic evidence that nitric oxide modulates homocysteine: the NOS3 894TT genotype is a risk factor for hyperhomocystenemia. Arterioscler Thromb Vasc Biol 2003, 23: I0|4-20

15I. Mc Donald DM, Alp NJ, Channon KM: Functional comparison of the endothelial nitric oxide synthase Glu298Asp polymorphic variant in human endothelial cells. Pharmacogenetics 2004, | 4:83|-9.

152. Fatini C, Sofi F, Gori AM, Sticchi E, Marcucci R, Lenti M, Casini A, Surrenti $C$, Abbate R, Gensini GF: Endothelial nitric oxide synthase
$-786 \mathrm{~T}>\mathrm{C}$, but not $894 \mathrm{G}>\mathrm{T}$ and $4 \mathrm{a} 4 \mathrm{~b}$, polymorphism influences plasma homocysteine concentrations in persons with normal vitamin status. Clin Chem 2005, 5 I : I I 59-64.

153. Nakayama $M$, Yasue $H$, Yoshimura $M$, Shimasaki $Y$, Kugiyama $K$, Ogawa H, Motoyama T, Saito Y, Ogava Y, Miyamoto Y, Nakao K: T$786->C$ mutation in the 5 '-flanking region of the endothelial nitric oxide synthase gene is associated with coronary spasm. Circulation 1999, 99:2864-7.

I54. Laule M, Meisel C, Prauka I, Cascorbi I, Malzahn U, Felix SB, Baumann G, Roots I, Stangl K, StangI V: Interaction of CA repeat polymorphism of the endothelial nitric oxide synthase and hyperhomocysteinemia in acute coronary syndromes: evidence of gender-specific differences. Mol Med 2003, 8 I :305-9.

155. Afman LA, Van Der Put NM, Thomas CM, Trijbels JM, Blom HJ: Reduced vitamin B I 2 binding by transcobalamin II increases the risk of neural tube defects. QJM 200I, 94:I59-66.

156. Anello G, Gueant - Rodriguez RM, Bosco P, Guent JL, Romano A Namour B, Spada R, Caraci F, Pourie G, Daval JL, Ferri R: Homocysteine and methylenetetrahydrofolate reductase polymorphism in Alzheimer's disease. Neuroreport 2004, I 5:859-6 I

I57. Balasa VV, Gruppo RA, Glueck CJ, Stroop D, Becker A, Pillow A, Wang $P$ : The relationship of mutations in the MTHFR, prothrombin, and PAI-I genes to plasma levels of homocysteine, prothrombin, and PAI-I in children and adults. Thromb Haemost 1999, 81:739-44.

I58. Dawson SJ, Wiman B, Hamsten A, Green F, Humphries S, Henney $A M$ : The two allele sequences of a common polymorphism in the promoter of plasminogen activator inhibitor-I (PAI-I) gene respond differently to interleukin-I in HepG2 cells. J Biol Chem 1993, 268:10739-10745.

159. Varela ML, Adamczuk YP, Forastiero RR, Martinuzzo ME, Cerrato GS, Pombo G, Carreras LO: Major and potential prothrombotic genotypes in a cohort of patients with venous thromboembolism. Thromb Res 2001, 1 04:317-24.

160. Ceelie H, Spaargaren-van Riel CC, Bertina RM, Vos HL: G202 I0A is a functional mutation in the prothrombin gene; effect on protein levels and 3'-end formation. J Thromb Haemost 2004 2:119-27.

16I. Bertina RM, Koeleman BP, Koster T, Rosendaal FR, Dirven RJ, de Ronde $\mathrm{H}$, van der Velden PA, Reitsma PH: Mutation in blood coagulation factor $V$ associated with resistence to activated protein C. Nature 1994, 369:|4-5.

Publish with Bio Med Central and every scientist can read your work free of charge

"BioMed Central will be the most significant development for disseminating the results of biomedical research in our lifetime. "

Sir Paul Nurse, Cancer Research UK

Your research papers will be:

- available free of charge to the entire biomedical community

- peer reviewed and published immediately upon acceptance

- cited in PubMed and archived on PubMed Central

- yours - you keep the copyright
Biomedcentral 